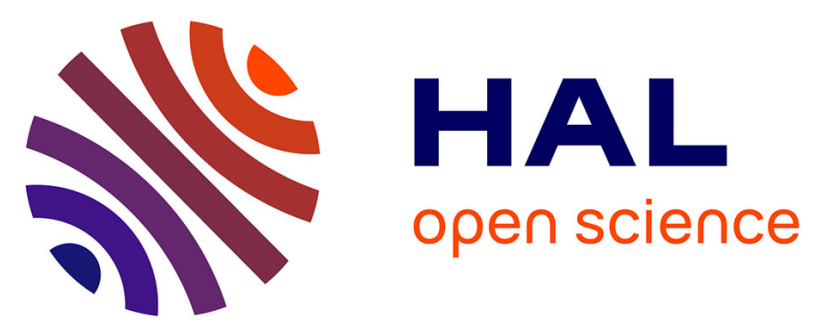

\title{
Reconstructing freshwater fishing seasonality in a neotropical savanna: first application of swamp eel (Synbranchus marmoratus) sclerochronology to a pre-Columbian Amazonian site (Loma Salvatierra, Bolivia)
}

Prestes-Carneiro Gabriela, Yunoki Takayuki, Dufour Jean-Louis, Mahé Kélig, Philippe Béarez

\section{- To cite this version:}

Prestes-Carneiro Gabriela, Yunoki Takayuki, Dufour Jean-Louis, Mahé Kélig, Philippe Béarez. Reconstructing freshwater fishing seasonality in a neotropical savanna: first application of swamp eel (Synbranchus marmoratus) sclerochronology to a pre-Columbian Amazonian site (Loma Salvatierra, Bolivia). Journal of Archaeological Science: Reports, 2021, 37, pp.102880. 10.1016/j.jasrep.2021.102880 . hal-03419400

\author{
HAL Id: hal-03419400 \\ https://hal.science/hal-03419400
}

Submitted on 8 Nov 2021

HAL is a multi-disciplinary open access archive for the deposit and dissemination of scientific research documents, whether they are published or not. The documents may come from teaching and research institutions in France or abroad, or from public or private research centers.
L'archive ouverte pluridisciplinaire HAL, est destinée au dépôt et à la diffusion de documents scientifiques de niveau recherche, publiés ou non, émanant des établissements d'enseignement et de recherche français ou étrangers, des laboratoires publics ou privés. 
Reconstructing freshwater fishing seasonality in a neotropical savanna: first application of swamp eel (Synbranchus marmoratus) sclerochronology to a preColumbian Amazonian site (Loma Salvatierra, Bolivia)

\section{Prestes-Carneiro Gabriela ${ }^{1,2 *}$; Yunoki Takayuki ${ }^{3}$; Dufour Jean-Louis ${ }^{4}$; Mahé Kélig ${ }^{4}$; Béarez Philippe $^{1}$}

${ }^{1}$ Archéozoologie, archéobotanique: sociétés, pratiques et environnements (UMR 7209 AASPE), MNHN, CNRS. Muséum national d'histoire naturelle. 55 rue Buffon, 75005, Paris (France)

${ }^{2}$ Anthropology and Archaeology Program, Institute of Social Sciences, Federal University of Western Para. Av. Mendonça Furtado, no 2946 - Fátima CEP 68040-470, Santarém - Pará (Brazil)

${ }^{3}$ Centro de Investigación de Recursos Acuáticos. Universidad Autónoma del Beni José Ballivián. Campus Universitario, Trinidad - Beni (Bolivia)

${ }^{4}$ Institut Français de Recherche pour l'Exploitation de la Mer (IFREMER), Sclerochronology Centre. 150 quai Gambetta, BP 699, 62321 Boulogne-sur-Mer (France)

*Corresponding author. Anthropology and Archaeology Program, Institute of Social Sciences, Federal University of Western Para. Av. Mendonça Furtado, no 2946 - Fátima CEP 68040-470, Santarém - Pará (Brazil).E-mail: gabi_prestes@ hotmail.com

\section{ABSTRACT}

Sclerochronology is a method used to estimate the season of death (season of capture) of archaeological individuals based on a modern growth model. This method has been increasingly accepted in South America and has mainly been applied to coastal archaeological sites (on the Atlantic and Pacific Ocean). This is the first time that this method has been applied to a freshwater species, the marbled swamp eel (Synbranchus marmoratus), in archaeology. Excavations undertaken at Loma Salvatierra, a human-built platform located in the Bolivian Amazon and occupied from 500 until 1400 AD, have yielded 111 zooarchaeological vertebrae of the marbled swamp eel, which is one of the most widely distributed species recovered in South American continental archaeological sites. In order to estimate the fishing season for these archaeological individuals, we developed a modern osteological reference collection, made up of 61 specimens with known capture dates sampled monthly over a one-year period, about $60 \mathrm{~km}$ from Loma Salvatierra. The vertebrae present periodic growth patterns with a succession of dark and light bands alternately. Consequently, the vertebrae are a reliable basis for the estimation of the marbled swamp eel fishing season. The analysis of the marginal increments of vertebrae in present-day fish 
allowed us to elaborate a modern growth model showing that the seasonal growth of the marbled swamp eel is related to the hydrological cycle, whereby the fast growth period coincides with the onset of rainfall in the region. On the basis of this modern-based model, the analysis of zooarchaeological vertebrae demonstrates that fish were captured over several seasons. Demonstrating that human groups occupied villages year-round does not mean that they were not mobile but shows year-round fishing in the savanna. This year-round fishing practice raises questions concerning the generalized idea of fishing as an exclusively dryseason activity. As wild resources are generally seasonal, the evidence of the year-round fishing of swamp eels might suggest year-round fishing at Loma Salvatierra and contributes to the understanding of late-Holocene mobility patterns in pre-Columbian times.

Keywords: Sclerochronology, Zooarchaeology, Llanos de Mojos, Synbranchus marmoratus, freshwater fishing

\section{INTRODUCTION}

One of the most accurate methods to estimate the season of occupation of riverine or coastal archaeological sites is the study of fish or mollusk growth structures, which allows for an estimation of the ontogenetic age, growth and season of death (capture period) of archaeological individuals (Casteel, 1974, 1972; Desse and Desse-Berset, 1992; Guillaud et al. 2017; Van Neer, 1993). In American archaeology, such studies have been increasingly applied to coastal environments (Hales and Reitz, 1992; Scartascini et al., 2015; Torres, 2006; Torres et al., 2020). However, very few studies have attempted to apply this approach to freshwater contexts (Cahiza, 2003; Svoboda, 2013). Despite the increasing interest in age determination and seasonality markers of modern freshwater tropical species, the analysis of growth-increment structures has been underexploited in South American archaeological contexts (Prestes-Carneiro et al. 2019, 2020).

Fishing was claimed to be a seasonal activity by the first scholars who studied the subsistence strategies adopted by pre-Columbian Amazonian groups (Moran, 1993; Roosevelt, 1980). Due to the scarcity of seasonality indicators, archaeological research carried out in the Amazon region frequently uses indirect evidence to indicate the seasonality of occupations. For example, Schaan (2008) carried out investigations within sites of the Amazon River estuary on Marajo Island that revealed a system of artificial temporary ponds that were filled by higher water levels during the rainy season. Associated overbank flooding led the author to suggest that fishing was mainly a dry-season activity. Similarly, in the 
Venezuelan Llanos, where Garson (1980) described systems of water-retention dikes and ponds across extensive savannas, dry-season fishing was suggested by aspects of fish ecology, such as the size of recovered fish communities and the dominance of droughttolerant fish. In the absence of biological evidence, the dry season character of fishing in both examples was only supported by indirect corroboration of periodicity.

In the 1950's and 1960's, the "sedentary versus nomadic" character of the strategies adopted by pre-Columbian Amazonian groups fueled a lively debate among the first archaeologists working in the region (Lathrap, 1968; Meggers, 1954). Around AD 1000 several regions of the Amazon were occupied by large societies with villages. There is evidence of monumentality in the form of earthworks, such as the roads that connected villages in the Xingu region, the mounds, defensive ditches, and circular villages in the central Amazon, the great extensions of black earth in the Santarém region, and the monumental platforms in the southwestern Amazon (Heckenberger et al., 2003; Neves et al., 2004; Prümers, 2004; Moraes and Neves, 2012). It is, however, difficult to understand the seasonality of resource use and occupations of these groups since the seasonality of past occupations is commonly inferred from density and extent of the archaeological settlements. These suggestions may be refined by direct study of archaeological remains (such as biorecorders) that contain markers of seasonality. Sclerochronology addresses ontogenetic age estimation, which refers to the time elapsed after birth, and growth, and can be used to explore a range of other themes such as the impact of human action on local ecology. This term is derived from the Greek, sclêros "hard", chronos "time", and logos "study" that together, mean the estimation of time by way of the growth marks on organisms' calcified (hard) structures. Sclerochronology is analogous to dendrochronology (the study of tree rings) in postulating that, as an animal grows, skeletal hard tissue records changes that are linked to environmental conditions and physiological processes. Thus, sclerochronology permits investigation of life-histories as well as environmental and climatic change across space and time. In calcified tissues, growth patterns can be seen under a reflected light, as a succession of alternately dark and light bands. A light band ("zone") represents a fastgrowing period and a dark band ("annulus") represents a slowdown in growth (see Fig 6). In many taxa, a couplet of one light and one dark band typically represents one annual growth cycle, although this may differ between tissue types (e.g., bone, otoliths, teeth, scales, vertebrae) (Beamish and McFarlane, 1983; Quitmeyer et al., 1997; Van Neer et al., 1999; Andrus et al., 2011; Meunier, 2012; Vitale et al., 2019). 
The presence of an annulus does not imply that an animal stopped growing, but it indicates a decrease in growth rate and metabolic activity (Quitmeyer et al., 1997; Panfili et al., 2002). The deposition of calcified tissue (increments) is commonly driven by factors related to temperature, such as seasonal contrasts, and the availability of water (Andrus et al., 2011). There are, however, many other potential factors related to internal rhythms (reproduction, sex reversal, migration, maturation) or external conditions (lack of food or water, water quality, salinity) that can affect growth and thus the increments formed. As such, sclerochronology can be used to study anthropogenic or naturally occurring impacts on natural resources and anthropogenic impacts on the local ecology (Campana, 1990; Panfili et al., 2002; Schone et al., 2008; Vitale et al., 2019).

Since the vast majority of fish are poikilothermic (organisms that do not control their internal temperatures), they are sensitive to external environmental variations, and are therefore potential bio-indicators of seasonal fluctuations. The increment for the last period of growth is used to estimate the season of death. Its measurement is made from the last annulus to the margin of the bone or otolith, which shows how much the individual has grown and lived since the last annulus formed (Casteel, 1972; Mahé, 2009; Torres et al., 2020).

As each type of calcified structure has a particular chemical composition and biomineralization process, specific studies are necessary to observe how each calcified structure records growth (Castanet et al., 1992; Panfili et al., 2002). The great majority of studies applying the sclerochronological approach to archaeological contexts are based on bivalve shells and fish otoliths (Andrus, 2011; Carré et al., 2005; Casteel, 1974; Hales and Reitz, 1992; Van Neer et al., 2004). Sclerochronological studies based on scale, pectoral spine, opercle, cleithrum, and vertebra are also possible, depending on the species and on the condition that increments are visible, regular and readable, although these studies are less common (Brewer, 1987; Desse and Desse-Berset, 1992; Morey, 1983; Guillaud et al., 2017). of South American freshwater fish based on calcified structures (Boujard et al., 1991; Cutrim and Batista, 2005; Fabré and Saint-Paul, 1998; Martins et al. 2009; Mateus and Petrere, 2004; Santos and Barbieri, 1993; Ponton et al., 2001). Baseline or proxy studies of modern living taxa need to be conducted to establish a model of growth relevant to the location of the archaeological site (Deith, 1983; Quitmeyer et al., 1997; Butler et al., 2019). Archaeological studies also require good preservation of the bone material, exhaustive 
sampling of archaeological remains using fine screen recovery, and modern comparative collections (Casteel, 1972; Rojo, 1988; Deith, 1983). The large majority of sclerochronological studies carried out with modern and archaeological samples have been developed in temperate latitudes, where the formation of growth increments is strongly related to winter versus summer contrasts (variations of temperature and photoperiodicity), even though the hard tissue formation is a complex phenomenon and not necessarily temperature-driven (Guillaud et al., 2017; Panfili et al., 2002). In tropical areas, where temperature gaps are less disparate, factors driving growth increment formation are complex and, for this reason, the impact of seasonality in archaeological assemblages requires careful modeling (Meunier, 2012).

Archaeological taxa with large sample sizes generate more accurate sclerochronological estimates of seasonality. Therefore, here we focus on the South American marbled swamp eel (Synbranchus marmoratus), which is one of the most abundant and widely distributed synbranchid species in Central and South America and a common taxon recovered in archaeological assemblages in the Amazon Basin, Pantanal wetlands and estuarine zones of Rio Grande do Sul (Prestes-Carneiro and Béarez, 2017; Prestes-Carneiro et al., 2018; Rosa, 2000, 2006). In south-western Amazonia, Synbranchus marmoratus comprises more than $70 \%$ of the fish remains recovered at Loma Salvatierra (Trinidad, Bolivia), a site was occupied from AD 500 to AD 1400 (Béarez and Prümers, 2005; Von den Driesch and Hutterer, 2012). Loma Salvatierra is an earthen platform mound that extends over 2 ha and reaches a height of $20 \mathrm{~m}$. In the Llanos de Mojos there are more than 100 human-built earthen mounds (Jaimes Betancourt and Prümers, 2018). These sites are frequently associated with other earth works, such as canals, ponds, and kilometers of causeways that radiate from the mounds and connect the sites together. The monumentality of these earth works raises questions about mobility and the interconnections between other groups, although no specific studies on mobility patterns or seasonality have been carried out. In order to address seasonality, we developed a modern reference collection of $61 S$. marmoratus skeletons collected monthly over a year. We established a growth increment model for the species based on the vertebrae, and applied it to the 111 vertebrae recovered at Loma Salvatierra. Here, we present the possible factors driving the formation of the annulus and use the model to estimate the seasonality of fishing activities and mobility in pre-Columbian times. 
Llanos de Mojos is the largest savanna in South America, extending over more than $200000 \mathrm{~km}^{2}$, between the Bolivian Andes and the southernmost border of the Amazonian rainforest. The monthly average temperature oscillates between 27 and $28^{\circ} \mathrm{C}$ from September until March. Temperatures slowly decrease from April to May and the lowest average values are reached in June-July $\left(23-24^{\circ} \mathrm{C}\right)$. They are highly affected by cold fronts (wet or dry) of wind coming from the south, the well-known surazos. These wind currents can lead to drastic decreases in temperatures, which can fall below $15^{\circ} \mathrm{C}$ for a few days (Fig 1) (Loubens et al., 1992).

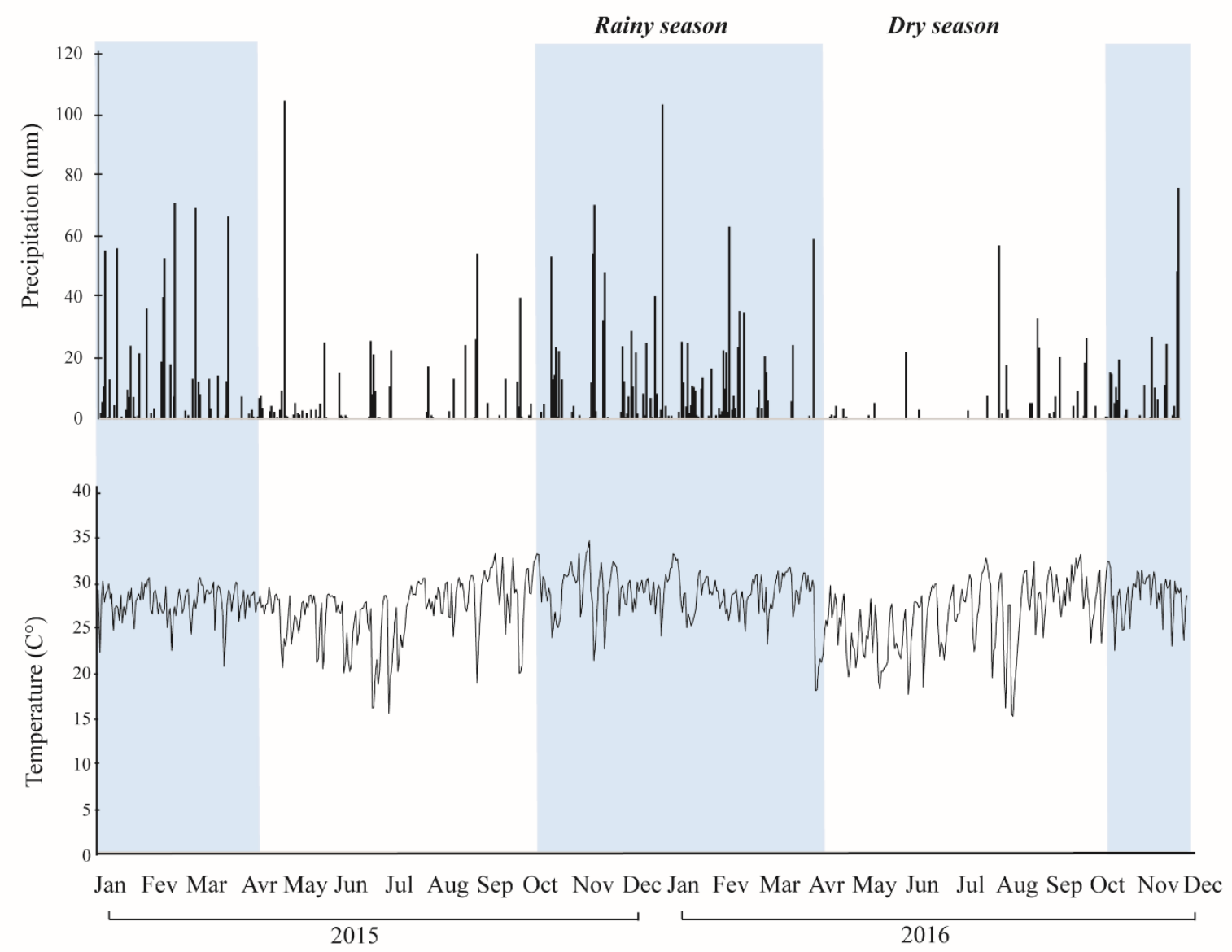

Fig 1: Temperatures and precipitation levels recorded at Trinidad (STLR station) in 2015 and 2016 (AASANA database available on www.aasana.bo).

In typical tropical areas, contrasts in temperatures are less extreme than in temperate regions, and major year-round changes in the landscape are therefore driven by precipitation fluctuations. In the study area more than $60-80 \%$ of rainfall coincides with the highest temperatures, occurring from December to March, and the annual average precipitation 
oscillates around $1200 \mathrm{~mm}$. From April, precipitation levels decrease and the dry season can last for over six months. The combination of rainfall and temperature defines a wet season running from November to April, and a dry season, which lasts from May to October (Hanagarth, 1993). These extensive low-altitude areas of Llanos de Mojos are drained by four main rivers: Madre de Dios, Beni, Itenez/Guaporé and its central axis, the Mamoré River. A combination of torrential rainfall and poor drainage of the soils drives the overflow of the main rivers, tributaries and shallow depressions. Denevan (1966: 11) estimates that over 50 percent of the territory of the Llanos de Mojos savannas is under water during maximum precipitation.

These flooding events had a huge impact on the management strategies adopted by the first Mojos groups settling in the region. Many artificial platforms of raised fields and canals (called lomas), identified in many areas of the Llanos de Mojos are indicative of the ability of such populations to deal with flooding and water constraints. Such is the case in Loma Salvatierra, a monumental platform located about $50 \mathrm{~km}$ to the east of Trinidad (Fig 2). The top of the platform contains three mounds laid out in a "U" shape, with the highest point reaching 7 meters. Loma Salvatierra is surrounded by a polygonal causeway encircling an area of 21 ha. Two sets of canals (about $300 \mathrm{~m}$ long) run from the main platform to an excavated pond which is itself connected to other ponds (Prümers, 2007). Far from the area of flooding of the Mamoré River, these ponds were probably supplied by precipitation water. A set of radiocarbon dates indicates that the site was built and occupied by five cultural groups between 500 and 1400 AD (Jaimes Betancourt, 2012; Prümers, 2007). Recent zooarchaeological studies carried out at Loma Salvatierra indicate that a high diversity of fishes, with species from at least 35 genera, were exploited and consumed, suggesting that, even in an interfluvial area, humans managed to exploit and deal with seasonal contrasts (Prestes-Carneiro et al., 2019). 


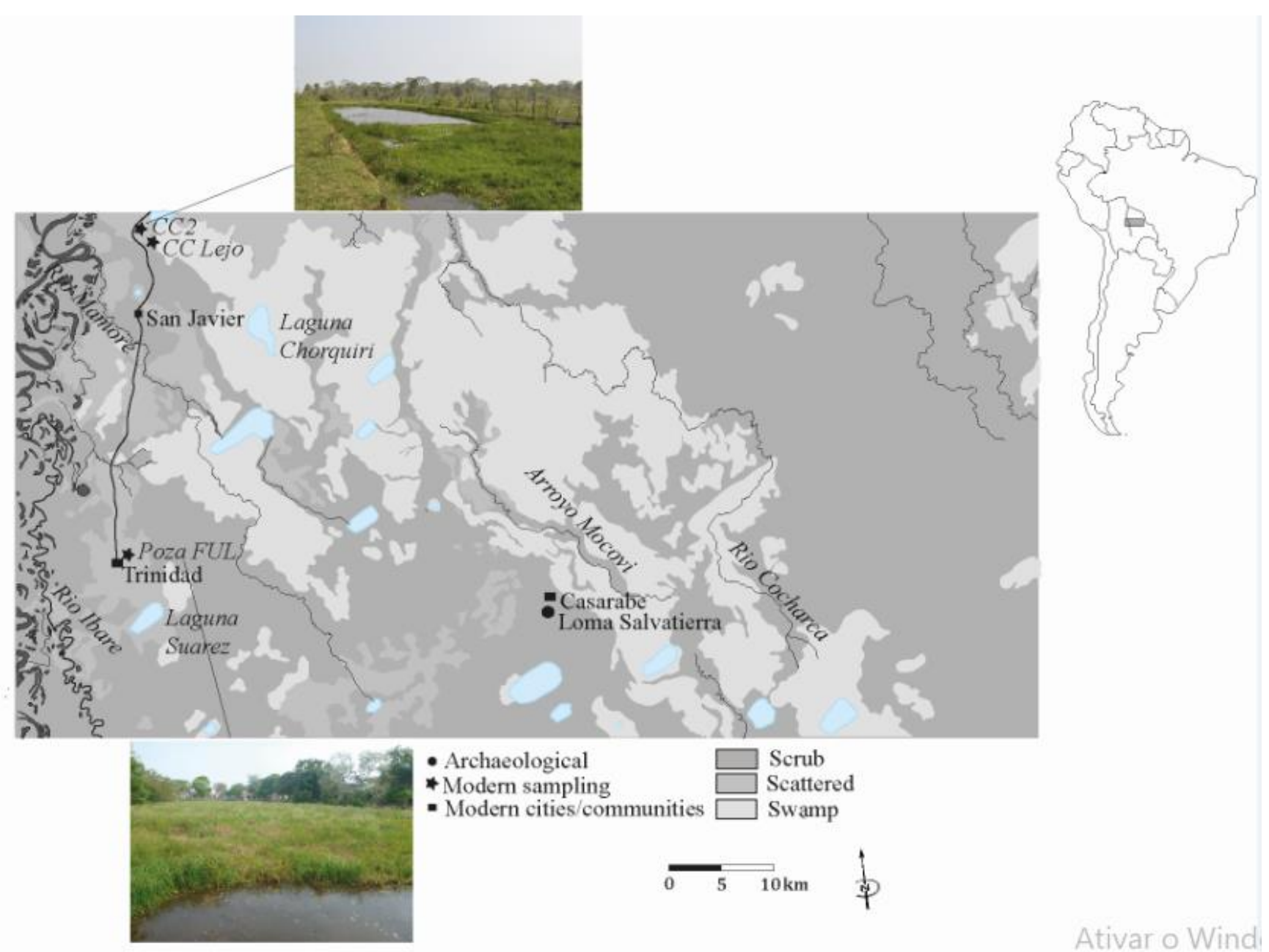

214 Fig 2: Map of Llanos de Mojos showing the distance between archaeological sites (Loma Salvatierra) and modern sampling areas (Poza FUL, CC2 215 and CC Lejo). 


\section{ECOLOGICAL OVERVIEW OF MARBLED SWAMP EEL}

218

The marbled swamp eel, Synbranchus marmoratus Bloch, 1795, is the most widely distributed Synbranchidae in the neotropics. Its present-day distribution encompasses the freshwater and estuarine areas of Central and South America (from Argentina to Guatemala and Mexico) (Lo Nostro and Guerrero, 1996). Genetic and systematic studies have yet to be developed and it is very likely that $S$. marmoratus is a complex of species (Perdices et al., 2005; Torres et al., 2005; pers. obs.). In order to avoid identification bias, we decided to sample individuals collected as near as possible to the archaeological site (Deith, 1983).

There are two recognized swamp eel species in the Llanos de Mojos (Rosen and Rumney, 1972), Synbranchus madeirae Rosen \& Rumney, 1972, and S. marmoratus. Synbranchids have a mucous-covered, scaleless, cylindrical eel-like body, and lack pelvic and pectoral fins. Their average length is $50 \mathrm{~cm}$ but the largest individuals reach up to 150 $\mathrm{cm}$. The form and skin patterns of $S$. marmoratus are highly variable compared to $S$. madeirae (pers. obs.) (Fig 3b). Swamp eels are very tolerant of high temperatures, even though they can also occur in subtropical regions (Rosen and Rumney, 1972), and can inhabit a variety of aquatic environments where shallow waters prevail (river shores, marshy areas, shallow ponds or lakes). Synbranchids have mechanisms of accessorial aerial breathing, and in the absence of water they can dig defined channels in the earth where they stay throughout the dry season (Bicudo and Johansen, 1979). As they are non-migratory fish, synbranchids are probably good indicators of local environmental fluctuations.

The marbled swamp eel is a protogynous diandric species where a high percentage of females change into males in the terminal phase. According to Lo Nostro and Guerrero (1996), there are therefore two types of males: 1) males born with reproductive male organs (primary males) and 2) females who, by sex reversal, have gonads transformed into functional testes. Lo Nostro and Guerrero (1996) estimate that sex reversal occurs when individuals reach between 56 and $91 \mathrm{~cm}$. It is expected that this process requires great energy. It is not known, however, whether this physiological process generates a false annulus in calcified structures.

Except for semi-arid Brazil (Rio Grande do Norte), where the reproductive period runs from July to August, the reproduction of marbled swamp eel seems to be highest during the austral summer, from November until March. On the Argentinean coast (province of Corrientes), females are mature by the end of summer (December to March). In São Paulo 
State (Americana, Brazil), maturation is reached at a total length of about $47 \mathrm{~cm}$ and reproduction takes place mainly from December to February (Barros et al., 2013; Gathaz, 2012; Lo Nostro and Guerrero, 1996). Age-based studies of S. marmoratus otoliths from northeastern Brazil have been carried out to characterize the dynamics of sex reversal (Barros et al., 2017). In the Llanos de Mojos, the age and period of maturation have not yet been studied.

Marbled swamp eel is mainly a generalist carnivore, feeding on detritus, protozoans, nematodes, insects, shrimps, crabs, mollusks, and fish. A case-study in the marshes of the Paraná River (Argentina) demonstrates that food intake seems to be related to rainfall levels, with higher food intake values during the rainfall period. This does not seem to be the case in Rio Grande do Norte (Brazil), where higher food intakes were observed during the low water period (Braga et al., 2009; Montenegro et al., 2011; Rodriguez, 1999).

\section{MATERIALS AND METHODS}

\subsection{Present-day sampling}

Precipitation and temperature conditions may have slightly changed over the last 1,500 years in the Llanos de Mojos (Carson et al., 2014), however, we selected three ponds close to archaeological site (Fig 2) as the best proxies. "Poza FUL" is a pond located inside the University campus of the Universidad Autonoma del Beni (UABJB) in Trinidad (20S 295423 8361689); “CC2” (20L 298744 8406265) and "CC Lejo" (20L 297871 8408452) are ponds located between San Javier and San Pedro Nuevo, about $40 \mathrm{~km}$ to the north on the east side of the road connecting Trinidad and San Ramon (Fig 2). The three ponds are artificial and located about $60 \mathrm{~km}$ from the Loma Salvatierra archaeological site. These ponds are more than a dozen kilometers from the Mamoré River (and its floodplain), and are almost exclusively supplied by local precipitation. The fish community of these ponds is composed of wild populations adapted to seasonal periods of drought and flood events (Yunoki et al., 2018). Ponds measured about $50 \mathrm{~m}$ x $15 \mathrm{~m}$ and swamp eels were dispersed under floating vegetation, predominantly Pontederia subovata and Cyperus luzulae. The aquatic vegetation partially covering the ponds was cut and brought to the edge of the pond with the aid of a seine net ( $5 \mathrm{~mm}$ mesh size), and eels were then caught by hand (Fig 3a). 
The modern reference collection includes 61 individuals captured at the end of each month from July 2015 to July 2016, except for the month of February 2016. Information on specimens (size, fishing capture date, and sex) is available in Supplemental Table 1.

Specimens were kept frozen at the Centro de Investigaciones de Recursos Acuaticos (Trinidad) and two fieldwork campaigns were carried out to prepare the osteological material. To prepare the skeletons, frozen specimens were defrosted, cooked in boiling water and then macerated in water for 5 days. It is possible that a preparation at $100^{\circ} \mathrm{C}$ may have altered the microcrystalline structure of the vertebrae as has been observed for otoliths (Andrus and Crowe, 2002), however, we are assuming that this had no impact on the distribution of the annuli. Head length (HD) was measured from the tip of the snout to the posterior end of the branchial opening, total length (TL) was measured from the tip of the snout to the tip of the caudal fin, and pre-anal length (PAL) was measured from the tip of the snout to the anal vent. Sex identification was undertaken following the criteria described by Lo Nostro and Guerrero (1996). Growth increment analysis was then performed on the third precaudal vertebra at the Sclerochronology Centre of the Institut Français de Recherche pour l'exploitation de la Mer (IFREMER, Boulogne-sur-Mer, France). The skeletons are now part of the modern comparative collections of the Curt Nimuendaju Archaeological laboratory of the Federal University of Western Pará (UFOPA-Santarém). The zooarchaological samples were sorted at the Muséum national d'histoire naturelle (MNHN) in Paris (France), brought to IFREMER for reading, and are now housed at the Deutsches Archäologisches Institut, Kommission für Archäologie Außereuropäischer Kulturen (KAAK, Bonn, Germany).
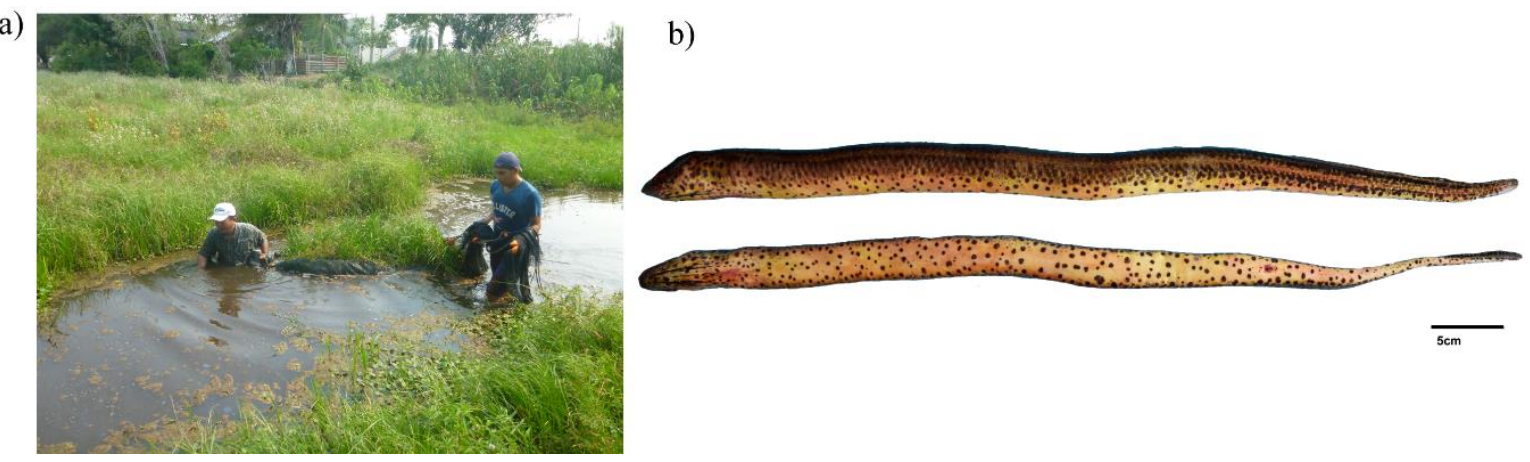

Fig 3: (a) The swamp eels were captured from under the floating vegetation of shallow ponds (b) Synbranchus marmoratus in lateral and ventral view 
Although the majority of sclerochronological studies on fish are carried out on otoliths or scales, archaeological scales were absent at Loma Salvatierra and otoliths presented a porous consistency, which prevented us from obtaining good quality, readable anatomical specimens. We thus decided to work on vertebrae, where increments were visible and readable. To compare zooarchaeological and modern samples, it is appropriate to work with vertebrae that are always located at the same place along the spine. We therefore constructed the global rachidian profile to test whether there was significant variation in size between pre-caudal and caudal vertebrae (Desse et al., 1989). The first 80 vertebrae of three different individuals were placed in a scanner and their diameters were analyzed and compared using the Traitement Numérique des Pièces Calcifiées (TNPC) software (https://www.seanoe.org/data/00320/43117/) (Mahé et al., 2011) (Fig 4). This software was developed specifically for analysis of calcified parts through sclerochronology. It can be noted that vertebra size decreases in relation to the position in the vertebral column (the diameter decreases gradually towards the caudal vertebrae), especially for larger specimens (Fig 4b).

After verifying the constancy of size variations, we selected a vertebra with an easily recognizable position in the vertebral column. The first, second and third precaudal vertebrae (v1, v2 and v3) are easily distinguishable from each other; however, annuli in v1 are too constricted. The diagnostic criteria distinguishing v2 from v3 are: a) v2 is shorter and flatter compared to $\mathrm{v} 3$; b) v2 presents a linear foramen in ventral view; c) the parapophyses are straight in v2 vs. curved in v3 (Fig 5). These criteria were used to identify the archaeological vertebrae, and the separation of v3. Between vertebrae 2 and 3, the latter is dominant in the archaeological assemblage, which justified our choice to model growth from v3. Only zooarcheological samples where conservation preserved the criteria mentioned above were used in this study. 
a)

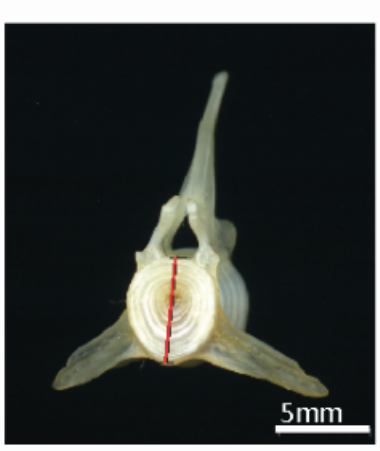

Legend:

$$
\begin{aligned}
& \Delta \# 1, \mathrm{TL}=830 \mathrm{~mm} \\
& * \# 24, \mathrm{TL}=450 \mathrm{~mm} \\
& \text { - \#33, } \mathrm{TL}=530 \mathrm{~mm}
\end{aligned}
$$

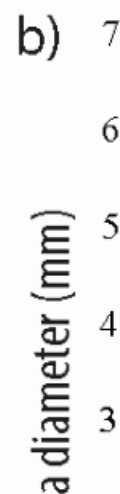

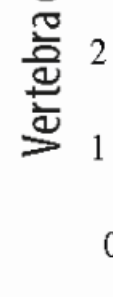
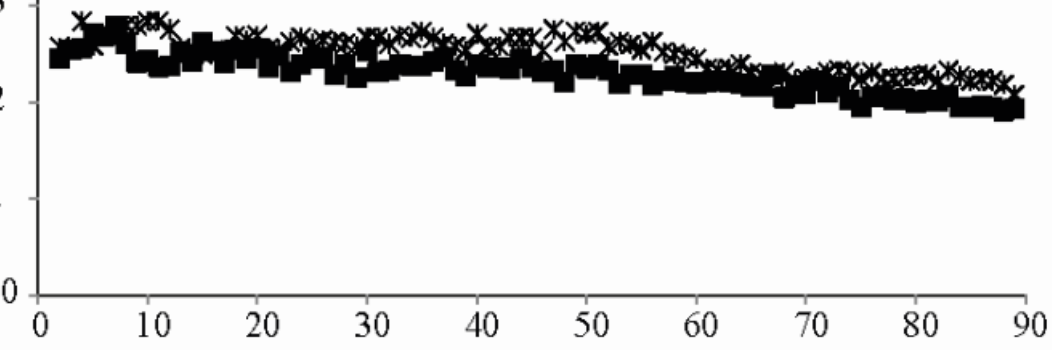

Vertebra number
335

336

337

338

339

340

341

342

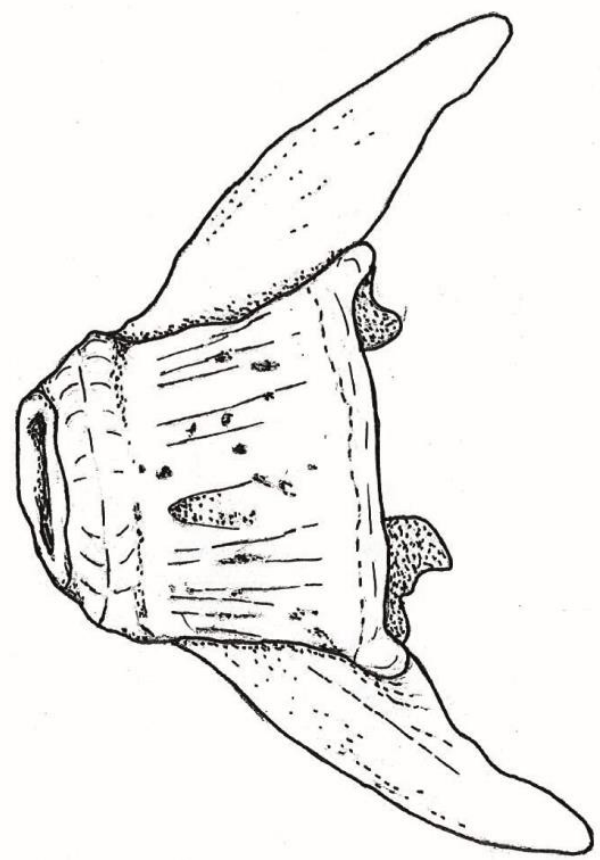

ver 2

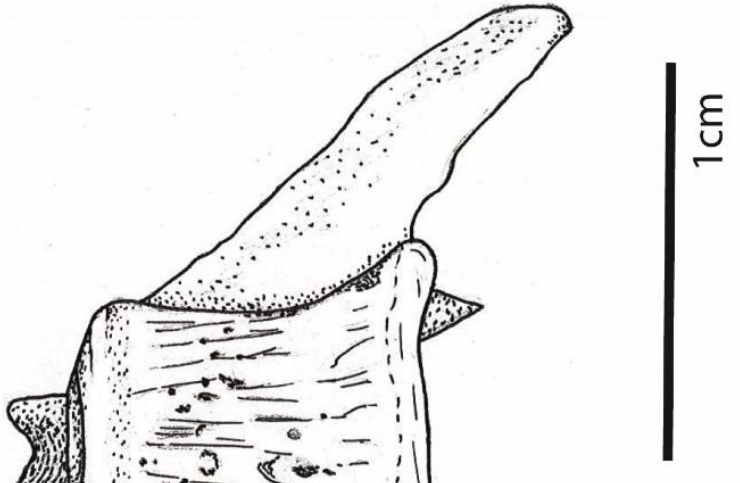

ver 3

Fig 4: (a) In cranial view, the dorso-ventral diameter of each vertebra was measured in order to elaborate the rachidian profile and evaluate size variation in vertebrae along the vertebral column; (b) global rachidian profile showing pre-caudal and caudal vertebral diameters of individuals of different sizes where (\#) is the specimen number and (TL) is the total length. The caudal vertebrae of the larger specimen presented a more pronounced decrease in size. 
Fig 5: Ventral view of vertebrae 2 and 3 of marbled swamp eel (Synbranchus marmoratus) (C) K. Dillenseger).

\subsection{Growth and Marginal Increment analysis}

In contrast to the great majority of teleostean fishes, marbled swamp eel vertebrae resemble more the opisthocoele than the amphicoele type, i.e., the vertebrae present a flat surface anteriorly (cranial view) and a concave, cone-shaped one, posteriorly (caudal view). Although the flat surface provides a better view of the increments, on this surface they are superposed. In the cone, the increments are more spaced out and readable, hence the caudal view was the most suitable for growth increment reading. Modern and archaeological v3 vertebrae were photographed using a stereomicroscope connected to a video camera and an image-analysis system (TNPC software). We used reflected light and a magnification of 1.25 for modern specimens and 1.6 for archaeological specimens. The reading axis (radius) was placed at the level of the right parapophysis of each vertebra from the center of the chordal centrum (focus) to the greatest distant margin (Fig 6). Measurements between each annulus were taken from the focus to the marginal edge of each vertebra. Readings were taken twice by the same expert to limit bias. With image analysis, we validated the annual periodicity of the annulus as shown by the sinusoidal regression (Supplemental Fig 1).

In order to estimate the season of capture, we used the Marginal Increment (MI), a ratio that expresses the state of completion of the forming growth increment in relation to the last completed increment, based on measurements of the distances between the focus and: 1) the marginal edge of the vertebral cone, 2) the outermost (ultimate) annulus, and 3) the penultimate annulus (Fig 6). MI also normalizes the sizes between individuals to be able to compare them (Beamish and McFarlane, 1983):

$$
\left.\mathrm{MI}=\left(\mathrm{R}-\mathrm{r}_{\mathrm{n}}\right) / \mathrm{r}_{\mathrm{n}}-\mathrm{r}_{\mathrm{n}-1}\right)
$$

where:

$\mathrm{R}=$ vertebra radius from the focus to the marginal edge

$r_{n}=$ distance from the focus to the outermost annulus

$r_{n-1}=$ distance from the focus to the penultimate annulus

In modern samples, the marginal edge of the vertebra is covered by an intervertebral ligament that can be confounded with a zone (fast growth increment). In order to avoid this bias, we measured the radius to slightly before this false dark increment. It is worth noting 
that this phenomenon has also been described among Pseudoplatystoma fasciatum vertebrae (Panfili, 1992). The Kruskal-Wallis test was used to test the differences of MI among months at a 0.05 significance level as MI were not normally distributed. Tests of linear relationship between fish length and weight were made after logarithmic transformation of the data. Each linear relationship between two descriptors of fish (length and weight) or otolith (radius) was tested (Reitz et al., 1987). Statistical analyses were performed using the open-source statistical package environment R ( $\mathrm{R}$ Core Team, 2016). Differences were considered significant at $\mathrm{p}<0.05$.

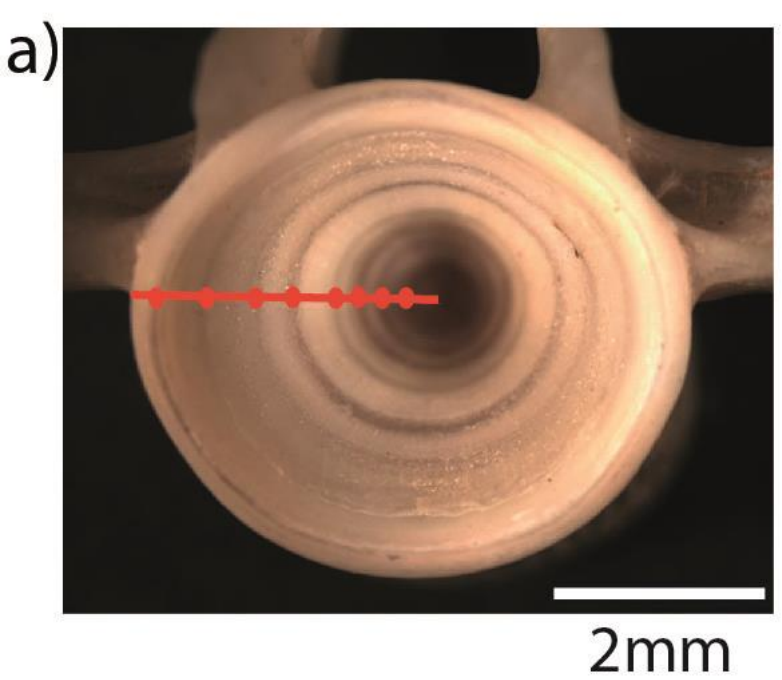

$2 \mathrm{~mm}$

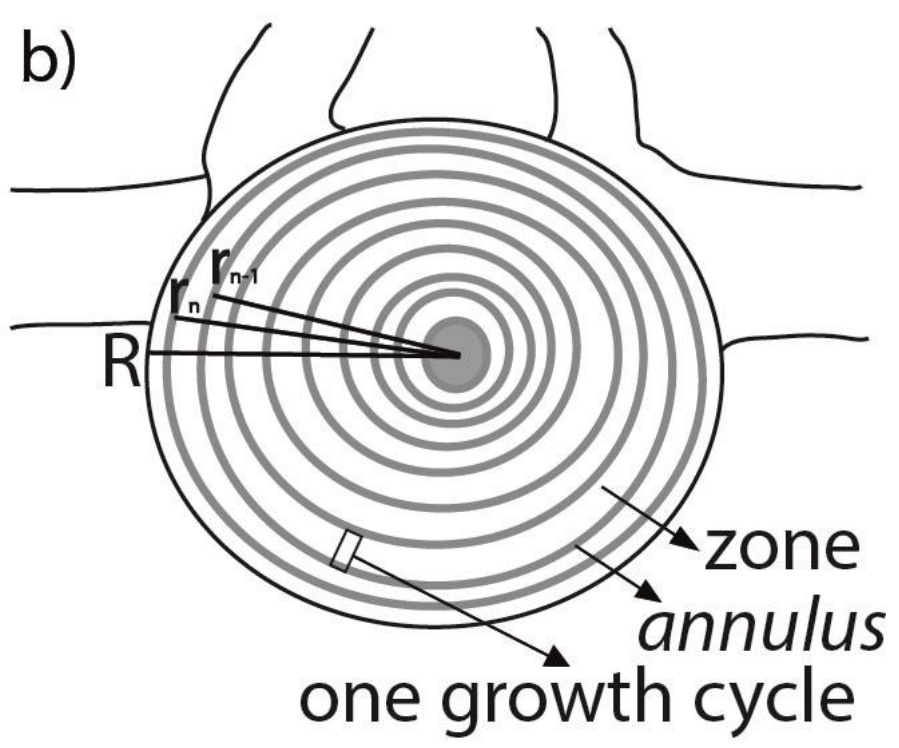

Fig 6: Caudal view under reflected light of (a) modern specimen and (b) schematic vertebra. The reading axis was placed in front of the paraphophysis, from (grey area) the focus to the marginal edge of the vertebral cone. $\mathrm{R}=$ distance from the focus to the marginal edge (radius) $; r_{n}=$ distance from the focus to the outermost annulus; $r_{n-1}=$ distance from the focus to the penultimate annulus. Annuli corresponding to periods of slow growth are marked by dots on the reading axis (in red).

\subsection{Archaeological sampling}

Archaeofaunal material was recovered from Loma Salvatierra by wet sieving with meshes of $2 \mathrm{~mm}, 1 \mathrm{~mm}$, and $0.5 \mathrm{~mm}$ (Pretes-Carneiro and Béarez, 2017). Taxonomic identification was carried out using modern comparative collections in order to identify the zooarchaeological specimens. The reference collection is housed at the Zooarchaeology 
laboratory (UMR 7209) of the MNHN (Paris). From remains of Synbranchus spp. we sorted 111 precaudal vertebrae (v3) representing 111 individuals. These vertebrae came from the five different periods or occupation phases of the site that have calibrated radiocarbon dates ranging between $\mathrm{AD} 500$ and $\mathrm{AD} 1400$ (Jaimes Betancourt, 2012). The sampling distribution of individuals sampled from the oldest to the most recent phase was: Phase 1 $(\mathrm{N}=14)$, Phase $2(\mathrm{~N}=9)$, Phase $3(\mathrm{~N}=42)$, Phase $4(\mathrm{~N}=43)$ and Phase $5(\mathrm{~N}=2)$. Since we were not able to distinguish $S$. marmoratus from $S$. madeirae on the basis of the vertebrae, taxonomic identification was based on the dentary and ectopterygoid bones. From these data, we observed that $S$. marmoratus corresponds to about $94 \%$ of the identified Synbranchus species at Loma Salvatierra (Prestes-Carneiro et al., 2019). We therefore assume here that the great majority of the archaeological samples correspond to this species and a model for S. marmoratus can be applied.

\section{RESULTS}

\subsection{The annual growth increment pattern of modern specimens}

The modern reference collection consists of 61 individuals of Synbranchus marmoratus with total lengths (TL) distributed between 145 and $740 \mathrm{~mm}$ and net weights (W) ranging from 3 to $811 \mathrm{~g}$. The species showed slightly positive allometric growth, where a significant relationship is given by the formula: $\mathrm{W}=6^{*} 10^{-7} * \mathrm{TL}^{3.134}\left(\mathrm{~N}=61, \mathrm{r}^{2}=0.9382, \mathrm{P}<0.05\right)$. Furthermore, there was a significant relationship between measurements (radius) of the third vertebra and the total length of individuals, where $\mathrm{TL}=315.72 *$ radius $^{0.669}\left(\mathrm{~N}=61, \mathrm{r}^{2}=0.88\right.$, $\mathrm{P}<0.05)$. This result means that vertebral development is closely related to the growth of the individual, which is a condition for incremental analysis.

Growth increments of $S$. marmoratus are regularly spaced and distinctly developed for the 61 modern vertebrae analyzed. Under reflected light, a dark zone with a diameter of around $0.81 \mathrm{~mm}$ surrounds the centrum of the vertebra. Panfili et al. (2002) attribute this zone to hatching, a hypothesis that should be further investigated. This first increment is followed by a broad and light increment (= zone) that probably corresponds to a fast growth period and a dark increment (= annulus), corresponding probably to a low growth period (Fig 7). Marbled swamp eel vertebrae present regular annuli with an annual periodicity (Supplemental Fig 1). 
Marginal Increment (MI) varies between 0.3 and 1.2. The zone starts to form in October; higher values of marginal increment are reached between November and December, which corresponds to the beginning of rainfall (Fig 8). There is a decrease in MI in January (0.4). The Kruskal-Wallis test and Pairwise Wilcoxon Rank Sum test were used to test the differences of MI among months at a 0.05 significance level as MI were not normally distributed. We see differences, but these differences are not significant at the $5 \%$ threshold.

We observed that individuals with a total length of no more than $30 \mathrm{~cm}$ had mature eggs, and that the vast majority of specimens carrying mature eggs were recovered in October, just before the first rainfall. Data from January and February must be interpreted with caution given the small number of individuals sampled during this period (Fig 8).

444 The slow growth period starting in January continues during the first semester of the year 445 (until June) with the lowest marginal increment recorded in May (0.2). It is interesting to 446 note that the slow growth in May corresponds to the drop in precipitation levels and the 447 beginning of the cool period with temperatures recorded for Trinidad reaching $15^{\circ} \mathrm{C}$ (see Fig 448 1). From June to October, growth increments are less regular and therefore difficult to 449 interpret.
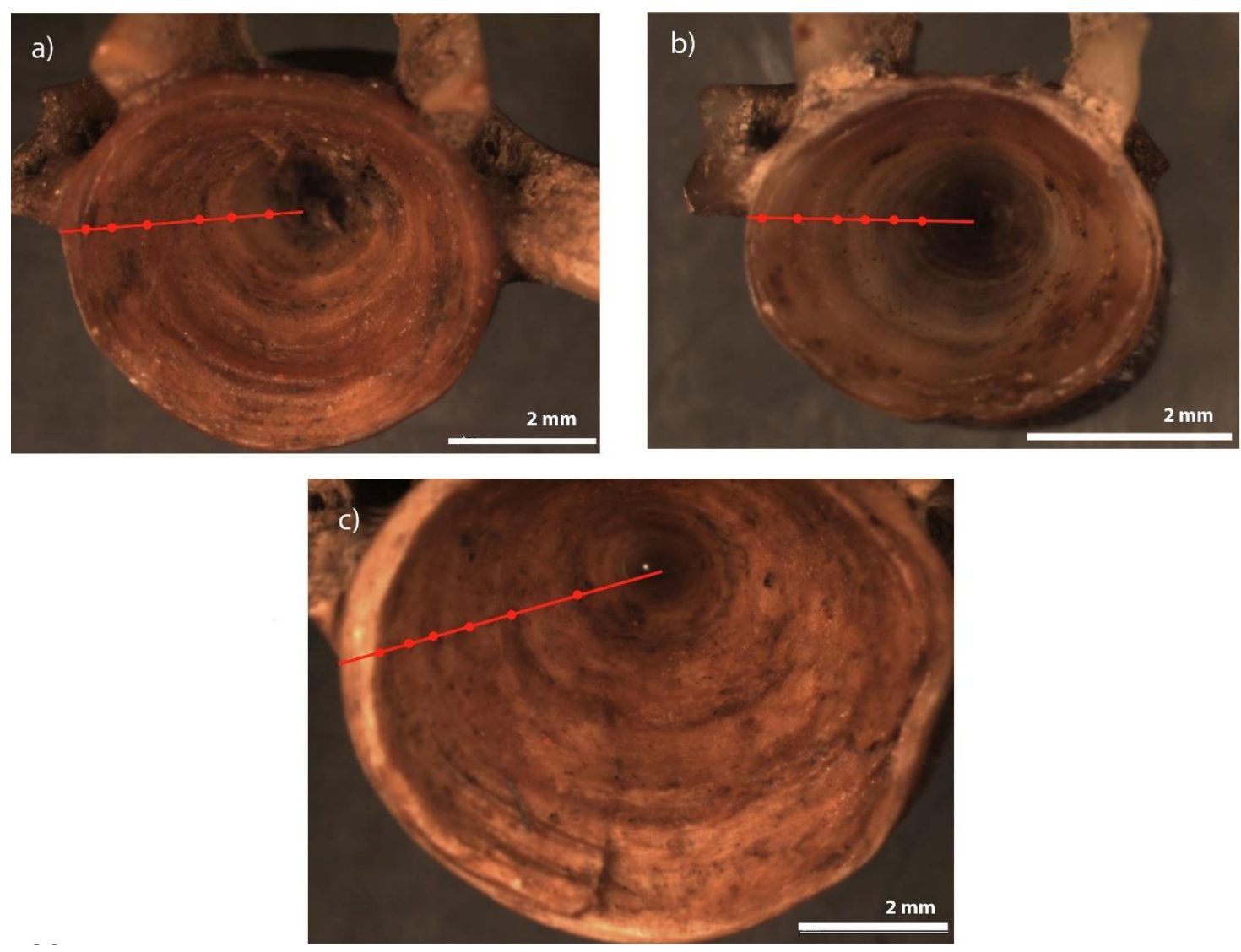

451 Fig 7: Zooarchaeological whole vertebrae of Synbranchus marmoratus. Annuli 452 corresponding to periods of slow growth are marked by dots on the reading axis (in red). 


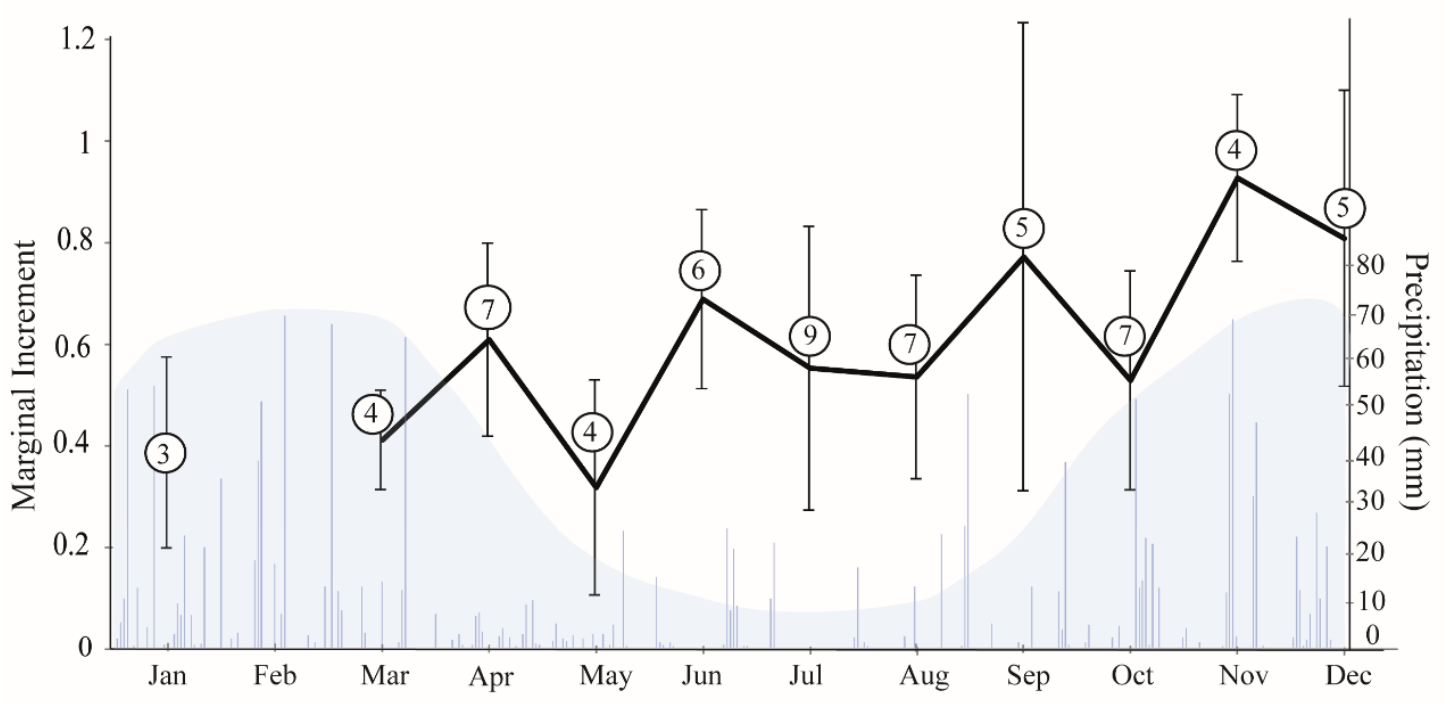

454 Fig 8: Marginal increment variation per month (solid line: mean \pm standard deviation) of

455

456

457

458

459

460

461

462

463

464

465

466

467

468

469

470

471

\subsection{Archaeological application}

The archaeological material recovered from Loma Salvatierra shows relatively little taphonomical deterioration. One hundred and eleven of the 138 vertebrae (v3) were preserved in good condition, showing visible annuli and thus considered suitable for age estimation, vertebrae were rejected when growth increments were not visible. We observed that some vertebrae presenting burning marks (white/grey/black colors) and deformed configuration, the measurements between annuli had lower values compared to the expected values (in relation to their corresponding class sizes). These vertebrae were also excluded. The marginal edges of the archaeological specimens were different: some of them were placed right on the annulus location, while for others, the edge was placed on zones. The marginal increments of vertebrae from distinct archaeological phases varied from 0.2 to 1.4. This is the case for phases 1 to 4 , however, this cannot be proven for phase 5 , where the number of preserved vertebrae is too low $(\mathrm{N}=2)($ Fig 9). 


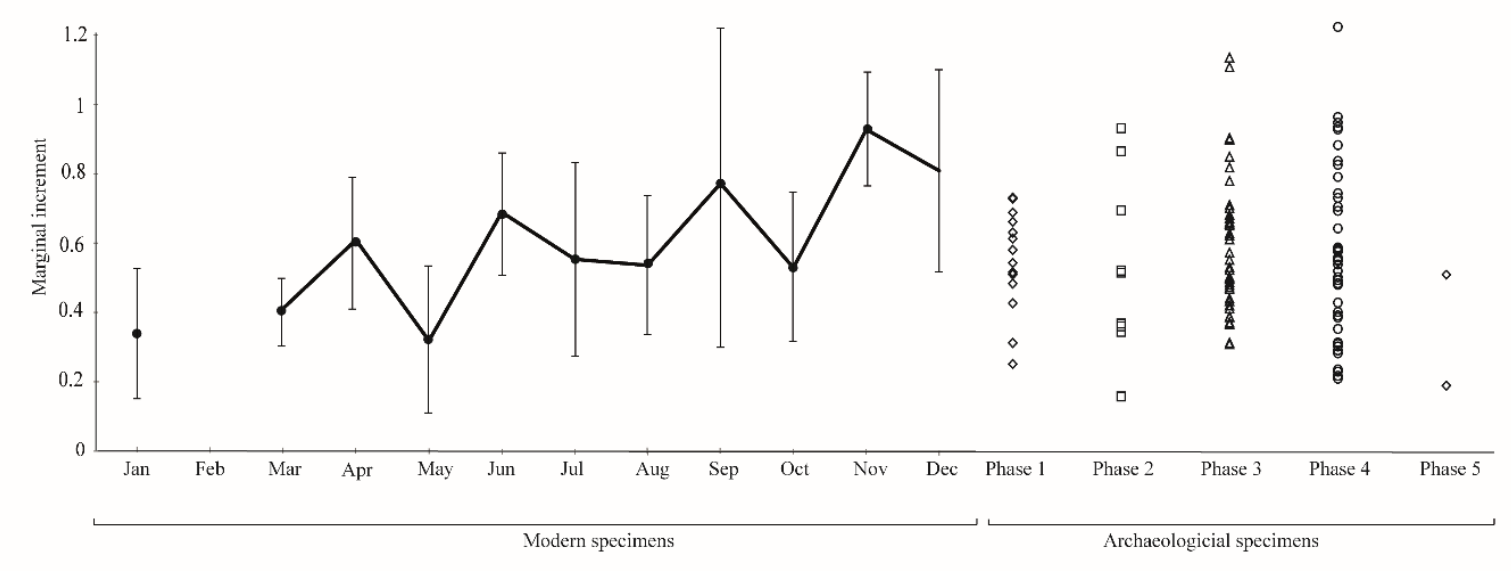

47:

473

474

475

476

477

478

479

480

481

482

483

484

485

486

487

488

489

490

491

492

493

494

495

496

Fig 9: Marginal increment (MI) values of the archaeological assemblage compared to the modern reference. As MI values of archaeological samples are well distributed between 0.2 and 1.2, we infer that individuals were captured during different seasons of the year.

\section{DISCUSSION}

The Llanos de Mojos aquatic environments and fauna are greatly affected by hydrological cycles. As water recedes, the fish fauna is concentrated in shallow water bodies and food availability decreases (Loubens et al., 1992; Panfili, 1992). As both modern and archaeological assemblages are from ponds mainly supplied by precipitation, the increase in marginal increments during the last months of the year (October, November and December) suggests that growth rates increase with the onset of heavy rainfall and the consequent food availability. As for many other tropical fishes, the marbled swamp eel growth pattern is influenced by the alternation of wet and dry seasons more than by the oscillation between summer and winter (Fabré and Saint-Paul, 1998; Junk et al., 1997; Lowe-McConnell, 1964; Meunier, 2012; Panfili, 1992; Silva and Stewart, 2006).

In this study, as the vast majority of female specimens were carrying eggs in October; as for many other tropical species, marbled swamp eel seems to present a gonadal maturation process synchronized with the beginning of the rainy season, but this should be verified since reproduction was not the focus of this study (Vazzoler and Menezes, 1992).

To date, near Trinidad, growth increment models have been established for five fish species: barred catfish (Pseudoplatystoma fasciatum), sabalo (Prochilodus nigricans), tambaqui-pacu (Colossoma macropomum), Amazon pellona (Pellona castelnaeana) and red-bellied piranha (Pygocentrus nattereri) (Duponchelle et al., 2007; Le Guennec and Loubens, 2004; Loubens and Panfili, 2000, 1997, 1992). In all these cases, the annulus is formed during the period of receding waters or the dry season (somewhere between August 
and November), whereas the light zone is formed during periods of rising waters. These data suggest that water level stress and the isolation of water bodies are the main drivers of annulus formation.

In our case, the annulus formation still needs to be validated with larger sample sizes. Despite the fact that many authors suggest that temperature fluctuations do not (or hardly) influence the growth pattern of Amazonian fish fauna (Fabré and Saint-Paul, 1998; Loubens and Panfili, 1992), our lower values of marginal increments coincide with the period when lowest temperatures are recorded (June and July). As commented above, such discrepancies in temperature values are driven by the arrival of cold windy fronts (surazos), when temperatures can drop as low as $6^{\circ} \mathrm{C}$ (albeit low mean temperatures do not drop below $15^{\circ} \mathrm{C}$ ). The low temperature of the surazos is explained by the origin of air masses: during the summer, the region is subject to humid winds from the northeast (Bolivian and Central Amazon region). In contrast, during the winter, cold fronts from the South Pole and the southernmost areas of South America reach the Llanos de Mojos, causing a drastic fall of 10 to $15^{\circ} \mathrm{C}$ from one day to another (Hanagarth, 1993).

These cold winds have been described since the first missionaries arrived in Mojos. By the end of the $18^{\text {th }}$ century, the Jesuit missionary Francisco Eder quoted "the winter is replaced by winds (...) before the waters start to recede, the new rains are blocked by these winds, which mark the end of the rainfall, they draw and dry the standing water spread throughout the savannas (...) With the exception of the surazo days, the heat is extreme, however, with the arrival of these winds, an extreme dryness overcomes the territory, followed by intense cold (Eder, 1985). The impact of the drop in temperature on faunal communities (mainly fish) has been also described by these first missionaries: "on the strength of the heat, the sudden wind from the south is so cold that it kills the fish in the rivers. They start in March and end in August-September" (Altamirano, 1979; Matthei and Jeria, 2001). Although the periods of slow growth coincide with the period when surazos occur, the impact of such drops in temperature, that could lower the water temperature, on incremental growth structures has yet to be investigated.

As postulated by Meunier (2012), growth increments can be driven by factors involving external environmental conditions and internal metabolic activity, which makes the interpretation of growth patterns difficult (Silva and Stewart, 2006). Therefore, our study is a first step and requires further investigation by enlarging the modern reference collection to include individuals of both species and of various age classes, investigating other calcified 
structures, and undertaking validation procedures, such as mark-recapture and rearing studies (Beamish and McFarlane, 1983; Campana, 2001; Hales and Reitz, 1992).

\subsection{Year-round fishing?}

The first scholars visiting the Mojos region described fishing as an important subsistence activity practiced not only by groups settling along major rivers but also in interfluvial areas (Métraux, 1942). As for fishing seasonality, fishing seemed to be mainly a dry season activity, at least for groups settled along the rivers, practiced as soon as water levels receded and schools were concentrated in water bodies (Métraux, 1942; Nordenskiöld, 2002 [1912], 2001 [1924]). For groups inhabiting interfluvial areas, however, the seasonality of fishing is less clear. At the beginning of the $20^{\text {th }}$ century, Mojos groups, who were among the groups living closest to the areas where Loma-type sites have been recovered, seemed to take advantage of the receding water period. Métraux (1942: 60) described fishing in Mojos as follows "Throughout the large Plains of Mojos (...) fishing was the most productive economic activity. Recession of floods left millions of fish stranded on the dry land or concentrated in small pools (...)”.

To date, little is known about the functioning of pre-Columbian fisheries in Mojos. In spite of that, great efforts have been made to document the ancient fish weir systems observed near Baures (about $150 \mathrm{~km}$ northeast of Loma Salvatierra). Due to the lack of biological information, Erickson (2000) and McKey et al. (2016) assumed that fishes were trapped as water receded, and thus presumed that fishing was a dry period activity. In Loma Salvatierra, however, as marginal increment analysis demonstrates that specimens were caught all year round, fishing may not have been an exclusively seasonal activity.

Evidence of year-round fishing is backed up by the presence of twisted pectoral fins in about $3 \%$ of the armored catfish Hoplosternum littorale specimens (total $\mathrm{N}=437$ ) recovered in Loma Salvatierra (Prestes-Carneiro et al., 2019). According to Reis (1998), in mature males, pelvic fin tips twist into a hook shape during the reproductive period. Therefore, if environmental conditions have not drastically changed during the last 1000 years, our observations indicate that some fishing of armored catfish could have taken place at the beginning of the rainy season (from December to March).

The modified landscape around the lomas in Llanos de Mojos can provide supplementary information about seasonality of the occupation of these sites. The density of villages concentrated in the territory, the architecture, and the monumentality of earth works 
led the archaeologists working on the region to suggest that these mounds were occupied by organized and densely populated societies that were inhabiting the sites throughout different periods of the year (Jaimes Betancourt and Prümers, 2018). If the ponds and canals were used during the dry season, it is probable that people did not abandon the site during this period. Furthermore, Loma Salvatierra is composed of dozens of successive, thin layers of sediment filled with archaeological material. Since no stratigraphic layer lacks archaeological material, there are no documented events of abandonment. This continuity reinforces the idea that people occupied the site permanently.

Archaeological evidence of a year-round occupation of Loma Salvatierra is also consistent with archaeobotanical evidence since this is another indicator of seasonality as some plants can have seasonal behaviors. The presence of chili peppers, sweet potatoes, jack beans, peanuts, squash, and other cultivars suggests that agricultural activities were probably practiced by sedentary groups living in Llanos de Mojos (Bruno, 2010). Another indicator of human groups dealing with seasonality in their agriculture comes from the soil engineering of raised fields. These systems were able to drain water related to overflooding during the rainy season and also to prolong the presence of water, turning the dry season into an additional cultivation period (Rodrigues et al., 2017, 2018).

The possibility of year-round fishing might be related (and explained) by the presence of artificial ponds near Loma Salvatierra. Mapping of the surroundings of Loma Salvatierra (Prümers, 2007, 2004) revealed a system of canals supplying excavated ponds that have a diameter of $35 \mathrm{~m}$ and a depth of $2 \mathrm{~m}$. The existence of continual fishing of marbled swamp eel indicates that fish were available during both dry and rainy seasons, supporting the hypothesis that some type of fishing management associated with earth works and ponds could have taken place at Loma Salvatierra and that ponds could have ensured the availability of these animals for a longer period of time (Prestes-Carneiro et al., 2019). This new evidence of year-round exploitation calls into question the general assumption that fishing was a seasonal activity (Roosevelt, 1980). We do not exclude the possibility that fishing could have been more intensive during the dry season, but our data reinforce the idea that fishing involves the ability to deal with seasonal constraints through the development of techniques, methods, and practices that take into account species behaviors and distribution in the environment (Gragson, 1992). Hence, as the complex network of natural and artificial depressions seems to have captured surplus seasonal rainfall and retained water during the dry season, Loma Salvatierra demonstrates that the construction of managed aquatic landscapes could have provided year-round resources. 
600

601

602

603

604

605

606

607

608

609

610

611

612

613

614

615

616

617

618

619

620

621

622

623

624

625

626

627

628

629

The application of a growth model to an archaeological assemblage is accompanied by a certain number of potential biases that could have compromised the accuracy of the analysis if they had not been taken into account: 1) The use of vertebrae raised taxonomic and rank identification problems; thus, it is of interest to verify the constancy of size along the vertebral column. 2) Despite the fact that vertebrae are solid bony structures, in some cases the marginal edges, which are essential for marginal increment analysis, can be eroded and unreadable. In the future, it would be interesting to use sections of vertebrae since the marginal edge can then be interpreted more easily on a flat structure than on a conic one (Desse and Desse-Berset, 1992; Rojo, 1988). 3) Since modern and archaeological fish may have been cooked or grilled at different temperatures and culinary practices, this could engender modifications in the form and size of the vertebrae and, therefore, we strongly recommend excluding clearly charred or deformed samples from the assemblage. A similar problem has also been pointed out by Andrus and Crowe (2002) for the analysis of overcooked archaeological otoliths.

Sclerochronological research should fundamentally comply with and verify this checklist of pre-requisites: archaeological specimen conservation, presence of readable noteroded increments, species level identification for the archaeological elements, verifying that the zooarchaeological element chosen for the study represents different individuals, collection of modern specimens from as close as possible to the archaeological site (Deith, 1983), carrying out collections every month of the year with the largest possible number of specimens. These are time-consuming tasks, albeit necessary for study quality.

A further consideration for the application of modern growth models to archaeological contexts is the assumption that environmental conditions (temperature, rainfall) have not changed so modern fish can be the model. Paleoclimatic data from southwestern Amazonia, such as the carbon isotope record of soil organic matter collected in the state of Rondônia (Brazil), indicate that the rainforest expanded over the savanna around 3,000 BP (De Freitas et al., 2001; Mayle et al., 2000; Taylor et al., 2010). This southward expansion, according to analysis of fossil pollen and macroscopic charcoal, appears to reach the Llanos de Mojos around 2,000 BP (Carson et al., 2014). The start of the construction of monumental platforms, around AD 300 or 1,650 BP (Jaimes Betancourt and 
Prümers, 2018) is contemporary with the rain forest reaching stability at a level comparable to the modern canopy rainforest. Forest expansion is compatible with evidence of increased water levels in Lake Titicaca (Cross et al., 2000). A visible change in the pollen record occurs during the occupation of the Llanos de Mojos, around the year AD 1000, when signs of anthropogenic fire are linked to small scale-deforestation and slash-and-burn agriculture (Urrego et al., 2013; Carson et al., 2014, Watling et al., 2017). This reinforces that humans were shaping landscapes and modestly changing forest ecology. It remains to be seen whether these changes have had an impact on animal populations (Henry and Cerrato, 2007).

The final issue about bias is related to the locations of ancient versus modern captures. The model presented here is based on swamp eels inhabiting ponds all year long, yet it is known that, in the absence of water, synbranchids burrow channels (Bicudo and Johansen, 1979). As the location of ancient captures is unknown, we have assumed that the archaeological specimens also came from ponds, which might not be the case. The growth pattern of swamp eels living in buried channels is not yet known and should be further investigated.

\section{CONCLUSIONS}

This study examined fishing seasonality in Amazonian archaeological contexts from marbled swamp eel (Synbranchus marmoratus) vertebrae. Despite the fact that the great majority of sclerochronological studies on fish are based on the analysis of otoliths, in Amazonian archaeological sites, these remains have not been found to be well-preserved. This led us to use sclerochronological techniques adapted to vertebrae. The anatomical identification of the second and third vertebrae permits the differentiation and quantification of individuals and the observation of the vertebrae in caudal view (conic part) provides a better visualization of growth increments. Vertebrae are therefore the most suitable calcified structures for age reading for this species. Based on a modern reference collection, we developed a model to estimate the fishing season of the marbled swamp eel. Their vertebrae present regular annuli suggesting that growth increments are related to environmental fluctuations. Our observations point to the existence of one growth cycle per year and confirm the results of Barros et al. (2017). The greatest fish growth occurred during the wet season when waters were rising, as for many other species in the Bolivian Amazon. The period of slowed growth (annulus formation) appears to have occurred simultaneously with 
the fall in precipitation levels and drop in temperatures, somewhere between May and October.

The analysis of 111 archaeological swamp eel vertebrae from the Loma Salvatierra site (Bolivia), spanning occupations from AD 500 to AD 1400, demonstrated that the fishing of swamp eels occurred all year-round. This supports the hypothesis that people living on this seasonally flooded savanna fished during all seasons either as permanent residents or as groups of people continually coming and going over the millennium, and whose activities left no signs of abandonment. While large expanses of water are present during the wetseason, dry-season fishing may have been enhanced by the use of permanent water management systems, such as those that have been recorded at Loma Salvatierra.

Demonstrating that human groups occupied villages year-round does not mean that these groups were not mobile. The presence of causeways is a great indicator of inter-site mobility as they could function as sidewalks. Furthermore, mobility is inherent to the exploitation of some seasonal Amazonian resources such as Brazil nuts and most palm trees as well as the hunting of certain animals. In other words, to understand human occupation in the Amazon it is necessary to break with the paradigms that hunter-fisher-gatherers did not return to places they previously used and that ceramic possessing farmers did not have practices that depended on mobility to acquire resources from beyond their own settlements. These categories of sedentarism or nomadism are external and should be questioned, especially within debates about seasonality of occupation, as suggested by Mongeló (2013) and Shock and Moraes (2019).

While the seasonal differences in fish growth are less pronounced in South American fresh waters than in the ocean, it was possible to investigate human fishing strategies in relation to the hydraulic cycle. This contributes to the conclusion that, for seasonality studies, indications from multiple proxies such as landscape transformations, study of plant remains, malacofauna, vertebrate animals, etc. should be taken into account (Sanger et al., 2019). These concerns are especially relevant for understanding the use of resources in the context of the dense human occupation of the Amazon, which is suggested by the large archaeological sites, especially around AD 1000 (Moraes and Neves, 2012).

Studies that seek to describe the ontogenetic age and growth of Amazonian fishes have been expanded in biology, while in archaeology the importance of fishing among preColumbian Amazonian societies is increasingly recognized. These two areas of study can continue to complement each other. The application of sclerochronology to other Amazonian archaeological contexts will be an opportunity to combine biological and archaeological 
data. Like fish, many other biological resources may inform on seasonality (e.g. mollusks, amphibians, reptiles). The analysis of seasonality based on archaeological remains can contribute to the understanding of how pre-Columbian groups dealt with Amazonian ecosystems, the seasonality of resources, and the impacts of human exploitation on a local scale.

\section{ACKNOWLEDGEMENTS}

The authors thank the director of the Centro de Investigaciones de Recursos Acuaticos (Trinidad), Federico Moreno Aulo and his team for their welcome and support. Reinaldo Cholima Bravo and Socrates Pinheiro Ortiz helped with the sex identification, and Carlos Josue Oliva Roca helped with osteological preparations. Estefany Peña Fiel authorized access to the Aquarium room facilities. We thank Celina Chantre and Romain Elleboode from the Sclerochronology Centre of the IFREMER (Boulogne-sur-mer) for their helpful support with sclerochonological analysis. We are grateful to Carla Jaimes Betancourt and Heiko Prümers for granting access to the archaeological material and Zulema Lehm, Silvia Ten and Hugo Salas for the logistic support during the fieldwork seasons in Mojos. We are grateful to Claide de Paula Moraes and Myrtle Shock for their help with archaeological discussions. Rebecca Rivero Guzmán from the Museo Botanico/CIBIOMA (Trinidad) undertook the identification of aquatic plants observed in the ponds. The authors thank the Bolivian Ministerio de Medio Ambiente y Agua for granting permits for the sampling and exportation of modern specimens for analysis abroad (Sampling Permit number UVSAP N ${ }^{\circ}$ 1269/2014 and Exportation Permit Number UVSAP Nº029/2016). The modern comparative collections are housed at the Curt Nimuendaju Archaeological laboratory of the Federal University of Western Pará (UFOPA-Santarém) and the zooarchaeological specimens are housed at the Deutsches Archäologisches Institut, Kommission für Archäologie Außereuropäischer Kulturen (KAAK, Bonn). We would like to thank the reviewers for their thoughtful comments that helped to improve the manuscript and Kirsteen MacKenzie for English review. Specimens and catalogue numbers are available in the Supplemental Table 1. This paper is part of the first author's doctoral thesis conducted at the Muséum national d'histoire naturelle in Paris, in the UMR 7209 "Archéozoologie, Archéobotanique: pratiques, societés et environnements" of the CNRS. A doctoral scholarship was provided by the Brazilian research agency (CAPES-BEX 0910/14-7), and 
CAPES, the Societé des Amis du Muséum, the UMR 7209, and the PEPS Fishweirs from the CNRS (dir. Doyle McKey) provided funding for fieldwork.

\section{REFERENCES}

Altamirano, D.F., 1979 [1700]. Historia de la mision de los Mojos. Instituto Boliviano de Cultura Biblioteca Jose Agustin Palacios, La Paz, Bolivia.

Andrus, C.F.T., Crowe, D.E., 2002. Alteration of otolith aragonite: effects of prehistoric cooking methods on otolith chemistry. Journal of Archaeological Science 29, 291299. https://doi.org/10.1006/jasc.2001.0694

Andrus, C.F.T., 2011. Shell midden sclerochronology. Quaternary Science Reviews 30, 2892-2905. https://doi.org/10.1016/j.quascirev.2011.07.016

Barros, N.H.C., Nascimento, W.S., Araújo, A.S., Souza, A.A., Chellappa, S., 2013. Biologia reprodutiva do muçum, Synbranchus marmoratus Bloch, 1795 no açude Marechal Dutra, Rio Grande do Norte, Brasil. Biota Amazônia 3, 39-47. http://dx.doi.org/10.18561/2179-5746/biotaamazonia.v3n1p39-47

Barros, N.H.C., de Souza, A. A., Peebles, E. B., Chellappa, S., 2017. Dynamics of sex reversal in the marbled swamp eel (Synbranchus marmoratus Bloch, 1795), a diandric hermaphrodite from Marechal Dutra Reservoir, northeastern Brazil. Journal of Applied Ichthyology 33(3), 443-449.

Beamish, R., McFarlane, G.A., 1983. The forgotten requirement for age validation in fisheries biology. Transactions of the American Fisheries Society 112, 735-743. https://doi.org/10.1577/1548-8659(1983)112<735:TFRFAV>2.0.CO;2

Béarez, P., Prümers, H., 2005. Prehispanic fishing at Loma Mendoza, Llanos de Moxos, Bolivia, in: Plogmann, H. (Eds.), Proceedings of the 13th Meeting. Internationale Archäologie: Arbeitsgemeinschaft, Symposium, Tagung, Kongress, Band 8 of the ICAZ Fish Remains Working Group. Presented at the The Role of Fish in Ancient Time, Verlag Marie Leidorf, Basel, pp. 3-10.

Bicudo, P.W., Johansen, K., 1979. Respiratory gas exchange in the airbreathing fish, Synbranchus mamoratus. Environmental Biology of Fishes 4 (1), 55-64. https://doi.org/10.1007/BF00005928

Boujard, T., Lecomte, F., Renno, J.-F., Meunier, F., Neveu, P., 1991. Growth in four populations of Leporinus friderici (Bloch, 1794) (Anostomidae, Teleostei) in French 
Guiana. Journal of Fish Biology 38, 387-397. doi:10.1111/j.1095$\underline{\text { 8649.1991.tb03128.x }}$

Butler, P.G., Freitas,P.S., Burchell, M., Chauvaud, L., 2019. Archaeology and sclerochronology of marine bivalves, in: Smaal, A.C., Ferreira, J.G, Grant, J., Petersen, J.K., Strand, O. (Eds.), Goods and Services of Marine Bivalves. Springer, Cham, pp. 413-444.Braga, A.L.C., dos Santos Pompeu, P., Carvalho, R.F., Ferreira, R.L., 2009. Dieta e crescimento de Synbranchus marmoratus (Bloch, 1975) (Pisces, Synbranchiformes) durante período de pré-estivação em uma lagoa marginal da bacia do São Francisco, Minas Gerais. Revista Brasileira de Zoociências 10, 133-138.

Brewer, D.J., 1987. Seasonality in the prehistoric Faiyum based on the incremental growth structures of the Nile catfish (Pisces: Clarias). Journal of Archaeological Science 14, 459-472. doi.org/10.1016/0305-4403(87)90032-X

Bruno, M., 2010. Carbonized plant remains from Loma Salvatierra, Department of Beni, Bolivia. Zeitschrift für Archäologie Außereuropäischer Kulturen 3, 153-208.

Cahiza, P.A., 2003. Ictioarqueología de las Lagunas de Guanacache (Mendoza, Argentina). Relaciones de la Sociedad Argentina de Antropología 28, 167-183.

Campana, S.E., 1990. How reliable are growth back-calculations based on otoliths? Canadian Journal of Fisheries and Aquatic Sciences 47, 2219-2227. doi.org/10.1139/f90-246

Campana, S.E., 2001. Accuracy, precision and quality control in age determination, including a review of the use and abuse of age validation methods. Journal of Fish Biology 59, 197-242. doi.org/10.1111/j.1095-8649.2001.tb00127.x

Carré, M., Bentaleb, I., Blamart, D., Ogle, N., Cardenas, F., Zevallos, S., Kalin, R.M., Ortlieb, L., Fontugne, M., 2005. Stable isotopes and sclerochronology of the bivalve Mesodesma donacium: potential application to Peruvian paleoceanographic reconstructions. Palaeogeography, Palaeoclimatology, Palaeoecology 228, 4-25. doi.org/10.1016/j.palaeo.2005.03.045

Carson, J.F., Whitney, B.S., Mayle, F.E., Iriarte, J., Prümers, H., Soto, J. D., Watling, J., 2014. Environmental impact of geometric earthwork construction in pre-Columbian Amazonia. Proceedings of the National Academy of Sciences 111(29), 1049710502.

Castanet, J., Meunier, F.J., Francillon-Vieillot, H., 1992. Squelettochronologie à partir des os et des dents chez les vertébrés, in: Baglinière, J.L., Castanet, J., Meunier, F.J., Conand, F. (Eds.), Tissus durs et âge individuel des vertébrés. Colloque 
National, Bondy, France, 4-6 Mars 1991. Colloque et séminaire ORSTOMINRA, pp. 257-280.

Casteel, R.W., 1972. Some archaeological uses of fish remains. American Antiquity 37, 404-419. https://doi.org/10.2307/278439

Casteel, R.W., 1974. On the remains of fish scales from archaeological sites. American Antiquity 39, 557-581. https://doi.org/10.2307/278905

Cross, S., Baker, P., Seltzer, G.O., Fritz, S.C., Dunbar, R.B., 2000. A new estimate of the Holocene lowstand level of Lake Titicaca, central Andes, and implications for tropical palaeohydrology. Holocene 10(1), 21-32.

Cutrim, L., Batista, V.S. 2005. Determinação de idade e crescimento do mapará (Hypophtalmus marginatus) na Amazônia Central. Acta Amazon 35, 85-92. http://dx.doi.org/10.1590/S0044-59672005000100013

Deith, Margaret R., 1983. Molluscan calendars: the use of growth-line analysis to establish seasonality of shellfish collection at the Mesolithic site of Morton, Fife, Journal of Archaeological Science 10(5), 423-440.

De Freitas, H. A., Pessenda, L. C. R., Aravena, R., Gouveia, S. E. M., de Souza Ribeiro, A., Boulet, R., 2001. Late Quaternary vegetation dynamics in the southern Amazon basin inferred from carbon isotopes in soil organic matter. Quaternary Research, 55(1), 3946.

Denevan, W.M., 1966. The aboriginal cultural geography of the Llanos de Mojos Bolivia. University of California Press, Berkley.

Desse, J., Desse-Berset, N., Rocheteau, M., 1989. Les profils rachidiens globaux. Reconstitution de la taille des poissons et appréciation du nombre minimal d'individus à partir des pièces rachidiennes. Revue de paléobiologie 8, 89-94.

Desse, J., Desse-Berset, N., 1992. Age et saison de mort des poissons: applications à l'archéologie, in: Baglinière, J.L., Castanet, J., Conand, F., Meunier, F.J. (Eds.), . Presented at the Tissus durs et âge individuel des vertébrés. Colloque National, Bondy, France, 4-6 Mars 1991, Colloque et séminaire ORSTOM-INRA, pp. 341-353.

Duponchelle, F., Lino, F., Hubert, N., Panfili, J., Renno, J.-F., Baras, E., Torrico, J.-P., Dugué, R., Nunez, J., 2007. Environment-related life-history trait variations of the red-bellied piranha Pygocentrus nattereri in two river basins of the Bolivian Amazon. Journal of Fish Biology 71, 1113-1134. https://doi.org/10.1111/j.1095$\underline{8649.2007 .01583 . x}$ 
Eder, F.J., 1985 [1791]. Breve descripción de las reducciones de Mojos. Historia boliviana, Cochabamba.

Fabré, N.N., Saint-Paul, U., 1998. Annulus formation on scales and seasonal growth of the Central Amazonian anostomid Schizodon fasciatus. Journal of Fish Biology 53, 111. https://doi.org/10.1111/j.1095-8649.1998.tb00103.x

Garson, A.G., 1980. Comment upon the economic potential of fish utilization in riverine environments and potential archaeological biases. American Antiquity 45, 562-567. https://doi.org/10.2307/279874

Gathaz, R.J., 2012. Condição relacionada ao hermafroditismo protogínico diândrico em Synbranchus marmoratus (Bloch, 1975) (Teleostei, Synbranchiformes, Synbranchidae) na represa de Salto Grande, Americana-SP (Master dissertation). Universidade Estadual Paulista Júlio de Mesquita Filho, Rio Claro, Brazil. http://hdl.handle.net/11449/99517

Gragson, T.L., 1992. Fishing the waters of Amazonia: Native subsistence economies in a tropical rain forest. American Anthropologist 94, 428-440. www.jstor.org/stable/680469

Guillaud, E., Elleboode, R., Mahé, K., Béarez, P., 2017. Estimation of age, growth and fishing season of a Paleolithic population of grayling (Thymallus thymallus) using scale analysis. International Journal of Osteoarchaeology 27, 683-692. https://doi.org/10.1002/oa.2595

Hales, L.S., Reitz, E.J., 1992. Historical changes in age and growth of Atlantic croaker, Micropogonias undulatus (Perciformes: Sciaenidae). Journal of Archaeological Science 19, 73-99. https://doi.org/10.1016/0305-4403(92)90008-Q

Hanagarth, W., 1993. Acerca de la geoecología de las sabanas del Beni en el noreste de Bolivia. Instituto de Ecología de La Paz, La Paz.

Heckenberger, M.J., Kuikuro, A., Kuikuro, U.T., Russell, J.C., Schmidt, M., Fausto, C., Franchetto, B., 2003. Amazonia 1492: Pristine forest or cultural parkland? Science 301, 1710-1714. https://doi.org/10.1126/science.1086112

Henry, K. M., Cerrato, R.M., 2007. The annual macroscopic growth pattern of the northern quahog hard clam Mercenaria mercenaria in Narragansett Bay, Rhode Island. Journal of Shellfish Research 26(4), 985-993.

Jaimes Betancourt, C., Prümers, H. 2018. A la sombra de los Andes. Arquitectura monumental en los Llanos de Mojos, in: Ghezii, I., Camacho, L.E.S. (Eds.), La Cooperación Científica Francesa en Latinoamérica: Avances Recientes en Datación 
y Arqueometría en los Andes. Institut Français d'Études Andines (IFEA), Plural, La Paz, pp. 253-273.Jaimes Betancourt, C., 2012. La cerámica de la Loma Salvatierra (Beni-Bolivia). Editora Plural, La Paz.

Junk, W.J., Soares, M.G., Saint-Paul, U., 1997. The fish, in: Junk, W.J. (Eds) The Central Amazon Floodplain. Springer, Berlin, pp. 385-408.

Lathrap, D.W., 1968. The "Hunting" economics of the Tropical Forest Zone of South America: An attempt at Historical perspective, in: Lee, R., Devore, I. (Eds.), Man the Hunter. Aldine Transaction, Chicago, pp. 23-29.

Le Guennec, B., Loubens, G., 2004. Biologie de Pellona castelnaeana (Teleostei: Pristigasteridae) dans le bassin du Mamoré (Amazonie bolivienne). Ichthyological Exploration of Freshwaters 15, 369-383. http://horizon.documentation.ird.fr/exldoc/pleins_textes/divers 10-12/010034660.pdf

Lo Nostro, F.L., Guerrero, G.A., 1996. Presence of primary and secondary males in a population of the protogynous Synbranchus marmoratus. Journal of Fish Biology 49, 788-800. https://doi.org/10.1111/j.1095-8649.1996.tb00079.x

Loubens, G., Lauzanne, L., Le Guennec, B., 1992. Les milieux aquatiques de la région de Trinidad (Béni, Amazonie bolivienne). Revue d'hydrobiologie tropicale 25, 3-21.

Loubens, G., Panfili, J., 1992. Estimation de l'âge individuel de Prochilodus nigricans (Teleostei, Prochilodidae) dans le Béni (Bolivie): protocole d'étude et application. Aquatic Living Resources 5, 41-56. http://horizon.documentation.ird.fr/exldoc/pleins_textes/cahiers/hydrob-trop/37736.pdf

Loubens, G., Panfili, J., 1997. Biologie de Colossoma macropomum (Teleostei: Serrasalmidae) dans le bassin du Mamoré (Amazonie bolivienne). Ichthyological Exploration of Freshwaters 8, 1-22.

Loubens, G., Panfili, J., 2000. Biologie de Pseudoplatystoma fasciatum et P. tigrinum (Teleostei: Pimelodidae) dans le bassin du Mamoré (Amazonie Bolivienne). Ichthyological Exploration of Freshwaters 11, 13-34.

Lowe-McConnell, R.H., 1964. The fishes of the Rupunini savanna district of British Guiana, Pt 1. Groupings of fish species and effects of the seasonal cycles on the fishes. Journal of the Linnean Society (Zoology) 45, 103-144. https://doi.org/10.1111/j.1096-3642.1964.tb00490.x

Mahé, K., Fave, F., Couteau, J., 2011. TNPC user guide. France: IFREMER (accessed December 9, 2019). https://archimer.ifremer.fr/doc/00032/14288/. 
Mahé, K., Bellail, R., Dufour, J. L., Boiron-Leroy, A., Dimeet, J., Duhamel, E., Elleboode, R., Felix, J., Grellier, P., Huet, J., 2009. Synthèse française des procédures d'estimation d'âge. Programme SIDEPECHE, Projet Système d'Informations Halieutiques Sous-Action Sclérochronologie. Vol. 1. IFREMER, Paris. https://archimer. ifremer.fr/doc/00000/7294/.

Man-Wai, R., Quignard, J.-P., 1982. Les sars Diplodus sargus (Linnée 1758) du Golfe du Lion: croissance et caractéristiques des débarquements aux criées de Sète et du Graudu-Roi. Revue des Travaux de l'Institut des Pêches Maritimes 46, 173-194.

Mateus, L.A.F., Petrere, M., 2004. Age, growth and yield per recruit analysis of the pintado Pseudoplatystoma corruscans (Agassiz, 1829) in the Cuiabá River basin, Pantanal Matogrossense, Brazil. Brazilian Journal of Biology 64, 257-264. http://dx.doi.org/10.1590/S1519-69842004000200011

Matthei, M., Jeria, R.M., 2001. Cartas e informes de misioneros jesuitas extranjeros en Hispanoamérica: selección, traducción, introducción y notas (1751-1778). Pontificia Universidad Católica de Chile, Santiago.

Martins, J.M.E., Rego, A.C.L., Pinese, J.F. 2009. Determinação da idade e crescimento de Hoplias malabaricus (Bloch, 1794) (Characiformes, Erythrinidae) na represa de Campim Branco I, Rio Araguari, MG. Rev Bras Zoociências 11, 261-268.

Mayle, F.E., Burbridge, R., Killeen, T.J., 2000. Millennial-scale dynamics of southern Amazonian rain forests. Science 290(5500), 2291-2294.

McKey, D.B., Durécu, M., Pouilly, M., Béarez, P., Ovando, A., Kalebe, M., Huchzermeyer, C.F., 2016. Present-day African analogue of a pre-European Amazonian floodplain fishery shows convergence in cultural niche construction. Proceedings of the National Academy of Sciences 113, 14938-14943. http://doi:10.1073/pnas.1613169114

Meggers, B.J., 1954. Environmental limitation on the development of culture. American anthropologist 56, 801-824. https://www.jstor.org/stable/663814

Métraux, A., 1942. The native tribes of eastern Bolivia and western Matto Grosso, Smithsonian Institution Bureau of American Ethnology. US Government Printing Office, Washington.

Meunier, F., 2012. Skeletochronological studies of cyclical growth of freshwater fishes in French Guiana. A review. Cybium 36, 55-62. http://sfi-cybium.fr/en/node/68

Mongeló, G., 2013. O formativo e os modos de produção: ocupações pré-ceramistas no Alto Rio Madeira-RO. PhD Thesis, Universidade de São Paulo, Brazil. 
Montenegro, L.A., Damasceno, D.N.F., Almeida, R.G., Chellappa, S., 2011. Biologia alimentar do mussum, Synbranchus marmoratus (Bloch, 1795)(Osteichthyes: Synbranchidae) no açude Marechal Dutra localizado no semi-árido brasileiro. Biota Amazônia 1, 45-52. http://dx.doi.org/10.18561/2179-5746/biotaamazonia.v1n2p45$\underline{52}$

Moraes, C.P., Neves, E. G., 2012. O ano 1000: adensamento populacional, interação e conflito na Amazônia Central. Amazônica-Revista de Antropologia 4(1), 122-148.

Moran, E.F., 1993. Through Amazonian eyes: The human ecology of Amazonian populations. University of Iowa Press, Iowa City.

Morey, D.F., 1983. Archaeological assessment of seasonality from freshwater fish remains: a quantitative procedure. Journal of Ethnobiology 3, 75-95. https://www.jstor.org/stable/20170168

Neves, E.G., Petersen, J.B., Bartone, R.N., Heckenberger, M.J., 2004. The timing of terra preta formation in the Central Amazon: archaeological data from three sites, in: Glaser, B., Woods, W.I. (Eds.), Amazonian Dark Earths: Explorations in Space and Time. Springer-Verlag, Heidelberg, pp. 125-134.

Nordenskiöld, E., 2001 [1915]. Exploraciones y aventuras de Sudamérica. APCOB, La Paz. Nordenskiöld, E., 2002 [1912]. La vida de los indios: El gran Chaco (Sudamérica). APCOB, La Paz.

Panfili, J., 1992. Estimation de l'âge individuel des poissons: méthodologies et applications à des populations naturelles tropicales et tempérées. $\mathrm{PhD}$ Thesis, Université Montpelier II, Montpellier, France.

Panfili, J., De Pontual, H., Troadec, H., Wrigh, P.J., 2002. Manual of fish sclerochronology. Ifremer-IRD coedition, Brest, France. https://archimer.ifremer.fr/doc/00017/12801/

Perdices, A., Doadrio, I., Bermingham, E., 2005. Evolutionary history of the synbranchid eels (Teleostei: Synbranchidae) in Central America and the Caribbean islands inferred from their molecular phylogeny. Molecular Phylogenetics and Evolution 37, 460-473. http://doi:10.1016/j.ympev.2005.01.020

Ponton, D., Mol, J.H., Panfili, J., 2001. Use of otolith microincrements for estimating the age and growth of young armoured catfish Hoplosternum littorale. Journal of Fish Biology 58, 1274-1285. http://doi:10.1111/j.1095-8649.2001.tb02285.x

Pouilly, M., Beck, S.G., Moraes, R., Ibanez, C., 2004. Diversidad biológica en la llanura de inundación del Río Mamoré: importancia ecológica de la dinámica fluvial. Centro de Ecologia Simón, Santa Cruz de la Sierra. 
Prestes-Carneiro, G., Béarez, P., 2017. Swamp-eel (Synbranchus spp.) fishing in Amazonia from pre-Columbian to present times. Journal of Ethnobiology 37, 380-397. https://doi.org/10.2993/0278-0771-37.3.380

Prestes-Carneiro, G., Béarez, P., Dillenseger, K., Yunoki, T. 2018. Size estimation of Synbranchus marmoratus and Synbranchus madeirae based on isolated cranial and post-cranial bones. Cybium 42, 201-207.

Prestes-Carneiro, G., Béarez, P., Shock, M.P., Prümers, H., Jaimes Betancourt, C. 2019. PreHispanic fishing practices in interfluvial Amazonia: zooarchaeological evidence from managed landscapes on the Llanos de Mojos savanna. PLoS ONE 14(5): e0214638. https://doi.org/10.1371/journal.pone.0214638

Prestes-Carneiro G., Béarez, P., Pugliese, Shock, M.P., Zimpel C.A., Pouilly, M., Neves E.G., 2020. Archaeological history of Middle Holocene environmental change from fish proxies at the Monte Castelo archaeological shell mound, Southwestern Amazonia. The Holocene, 0959683620941108. https://doi.org/10.1177/0959683620941108

Prümers H., Jaimes Betancourt C., 2014. 100 años de investigación arqueológica en los Llanos de Mojos. Arqueoantropológicas (4), 11-53.

Prümers, H., 2007. Der Wall führt zum See. Die Ausgrabungen 2005-2006 in der Loma Salvatierra (Bolivien). Zeitschrift für Archäologie Auls sereuropäischer Kulturen 2, 371-379.

Prümers, H., 2004. Charlatanocracia en Mojos, investigaciones arqueológicas en la Loma Salvatierra, Beni, Bolivia. Boletín de arqueología PUCP, 103-116.

Quitmyer, I. R., Jones, D. S., Arnold, W. S., 1997. The sclerochronology of hard clams, Mercenaria spp., from the south-eastern USA: A method of elucidating the zooarchaeological records of seasonal resource procurement and seasonality in prehistoric shell middens. Journal of Archaeological Science, 24(9), 825-840.

Rodrigues, L., Lombardo, U., Veit, H., 2018. Design of pre-Columbian raised fields in the Llanos de Moxos, Bolivian Amazon: Differential adaptations to the local environment? Journal of Archaeological Science: Reports, 17, 366-378.

Rodrigues, L., Lombardo, U., Canal Beeby, E., Veit, H., 2017. Linking soil properties and pre-Columbian agricultural strategies in the Bolivian lowlands: the case of raised fields in Exaltación. Quaternary International 438 (Part B), 143-155.

Rodriguez, M., 1999. El espectro trófico de juveniles de Synbranchus marmoratus (Synbranchiformes, Synbranchidae). Iheringia, sér. Zool 86, 137-143. 
R Core Team 2016. R: A language and environment for statistical computing. Foundation for Statistical Computing, Vienna, Austria. http://www.R-project.org/

Rojo, A., 1988. Excavated fish vertebrae as predictors in bioarchaeological research. North American Archaeologist 8, 209-226. https://doi.org/10.2190/QTDW-T2A0-P7G6QX2V

Roosevelt, A.C., 1980. Parmana: Prehistoric maize and manioc subsistence along the Amazon and Orinoco. New York Academic Press, New York.

Rosa, A., 2000. Zooarqueologia de alguns sítios do Pantanal Sul-matogrossense. Revista Clio de Arqueologia 14, 327-342.

Rosa, A.O., 2006. Caçadores de cervídeos no Litoral Central: o sítio RS-LC-96. Pesquisas. Antropologia, 223-248.

Rosen, D.E., Rumney, A., 1972. Evidence of a second species of Synbranchus (Pisces, Teleostei) in South America. American Museum Novitates 2497, 145. http://hdl.handle.net/2246/2704

Sanger, M.C., Quitmyer, I.R., Colaninno, C.E., Cannarozzi, N., Ruhl, D.L., 2019. Multipleproxy seasonality indicators: An integrative approach to assess shell midden formations from Late Archaic shell rings in the coastal southeast North America. The Journal of Island and Coastal Archaeology 15.3, 333-363.

Santos, G.B., Barbieri, G., 1993. Idade e crescimento do "piau gordura", Leporinus piau Fowler, 1941, na represa de Três Marias (estado de Minas Gerais) (Pisces, Ostariophysi, Anostomidae). Braz J Biol 53, 649-658

Scartascini, F.L., Sáez, M., Volpedo, A.V., 2015. Otoliths as a proxy for seasonality: The case of Micropogonias furnieri from the northern coast of San Matías Gulf, Río Negro, Patagonia, Argentina. Quaternary International, Archaeology of coastal hunter-gatherer occupations in the Southern Cone 373, 136-142. https://doi.org/10.1016/j.quaint.2014.11.046

Schaan, D.P., 2008. The nonagricultural chiefdoms of Marajó Island, in: Silverman, H., Isbell, W. (Eds.), The Handbook of South American Archaeology. Springer, New York, pp. 339-357.

Shock M,P., Moraes, C.P., 2019. A floresta é o domus: A importância das evidências arqueobotânicas e arqueológicas das ocupações humanas amazônicas na transição Pleistoceno/Holoceno. Boletim do Museu Paraense Emílio Goeldi. Ciências Humanas 14(2), 263-289. 
1030

1031

1032

1033

1034

1035

1036

1037

1038

1039

1040

1041

1042

1043

1044

1045

1046

1047

1048

1049

1050

1051

1052

1053

1054

1055

1056

1057

1058

1059

1060

1061

Schone, B., 2008. The curse of physiology-challenges and opportunities in the interpretation of geochemical data from mollusk shells. Geo-Marine Letters 28 (56), 269-285.

Silva, E.A., Stewart, D.J., 2006. Age structure, growth and survival rates of the commercial fish Prochilodus nigricans (bocachico) in North-eastern Ecuador. Environmental Biology of Fishes 77, 63-77. https://doi.org/10.1007/s10641-006-9055-y

Svoboda, A., 2013. Método para determinar la estacionalidad de ocupación de sitios arqueológicos de ambientes fluviolacustres de Patagonia a partir de la observación de otolitos de percas. La Zaranda de Ideas, Revista de Jóvenes Investigadores en Arqueología 9, 145-153. http://hdl.handle.net/11336/1279

Taylor, Z.P., Horn, S.P., Mora, C.I., Orvis, K.H., Cooper, L.W., 2010. A multi-proxy palaeoecological record of late-Holocene forest expansion in lowland Bolivia. Palaeogeogr Palaeoclimatol Palaeoecol 293(1-2), 98-107.

Torres, R.A., Roper, J.J., Foresti, F., Oliveira, C., 2005. Surprising genomic diversity in the Neotropical fish Synbranchus marmoratus (Teleostei: Synbranchidae): how many species? Neotropical Ichthyology 3, 277-284. http://dx.doi.org/10.1590/S167962252005000200005

Torres, J.E. 2016. La pêche chez les chasseurs-cueilleurs marins de la région du détroit de Magellan et des mers adjacentes, de l'Holocène moyen aux temps ethnographiques : rôle, technologie et stratégies saisonnières. PhD thesis, Université Paris 1 Panthéon Sorbonne.

Torres J., Mahé K., Dufour J.-L., Béarez P., San Román M., 2020. Characterizing seasonal fishing patterns and growth dynamics during the Middle and Late Holocene in the Strait of Magellan (Chilean Patagonia): Sclerochronological analysis of Salilota australis (Teleostei: Moridae) vertebrae. Journal of Island and Coastal Archaeology, 1-20. 10.1080/15564894.2020.1755393

Urrego, D. H., Bush, M. B., Silman, M. R., Niccum, B. A., De La Rosa, P., McMichael, C. H., Hagen, S., Palace, M., 2013. Holocene fires, forest stability and human occupation in south- western Amazonia. Journal of biogeography, 40(3), 521-533.

Van Neer, W., Löugas, L., Rijnsdorp, A. D., 1999. Reconstructing age distribution, season of capture and growth rate of fish from archaeological sites based on otoliths and vertebrae. International Journal of Osteoarchaeology, 9(2), 116-130. 

https://doi.org/10.1002/(SICI)1099-1212(199903/04)9:2<116::AID$\underline{\mathrm{OA} 465>3.0 . \mathrm{CO} ; 2-\mathrm{H}}$

Van Neer, W., 1993. Limits of incremental growth in seasonality studies: The example of the clariid pectoral spines from the Byzantino-Islamic site of Apamea (Syria; sixth to seventh century AD). International Journal of Osteoarchaeology 3, 119-127. https://doi.org/10.1002/oa.1390030209

Van Neer, W., Ervynck, A., Bolle, L.J., Millner, R.S., 2004. Seasonality only works in certain parts of the year: the reconstruction of fishing seasons through otolith analysis. International Journal of Osteoarchaeology 14, 457-474. https://doi.org/10.1002/oa.727

Vazzoler, A., Menezes, N.A., 1992. Síntese de conhecimentos sobre o comportamento reprodutivo dos Characiformes da América do Sul (Teleostei, Ostariophysi). Revista Brasileira de Biologia 52, 627-640.

Vitale, F., Worsøe Clausen,L., Ní Chonchúir, G. (Eds.), 2019. Handbook of fish age estimation protocols and validation methods. ICES Cooperative Research Report 346. 180 pp. http://doi.org/10.17895/ices.pub.5221

Von den Driesch, A., Hutterer, R., 2012. Mazamas, patos criollos y anguilas de lodo. Restos de subsistencia del asentamiento precolombino "Loma Salvatierra", Llanos de Mojos, Bolivia. Zeitschrift für Archäologie Außereuropäischer Kulturen 4, 341-367.

Watling, J., Iriarte, J., Mayle, F. E., Schaan, D., Pessenda, L. C., Loader, N. J., StreetPerrottf, F.A., Dickau, E.G., Damascenod, A., Ranzi, A. 2017. Impact of preColumbian "geoglyph" builders on Amazonian forests. Proceedings of the National Academy of Sciences, 114(8), 1868-1873.

Yunoki, T., Torres, L. V., Cholima, R. B., 2018. A metacommunity ecological approach to understanding the community organization of fish in artificial ponds of the Mamore River floodplain in the Amazonian lowlands of Bolivia. Environmental Biology of Fishes, 101(9), 1329-1341. 
Supplemental material for Reconstructing freshwater fishing seasonality in a neotropical savanna: first application of swamp eel (Synbranchus marmoratus) sclerochronology to a pre-Columbian Amazonian site (Loma Salvatierra, Bolivia)

Prestes-Carneiro Gabriela ${ }^{1,2^{*}}$; Yunoki Takayuki ${ }^{3}$; Dufour Jean-Louis ${ }^{4}$; Mahé Kélig ${ }^{4}$; Béarez Philippe $^{1}$

Supplemental Figure 1: Temporal dynamics of monthly marginal increments on vertebrae of swamp eel $(n=61)$ with sinusoidal regression showing the annual periodicity of the annulus.

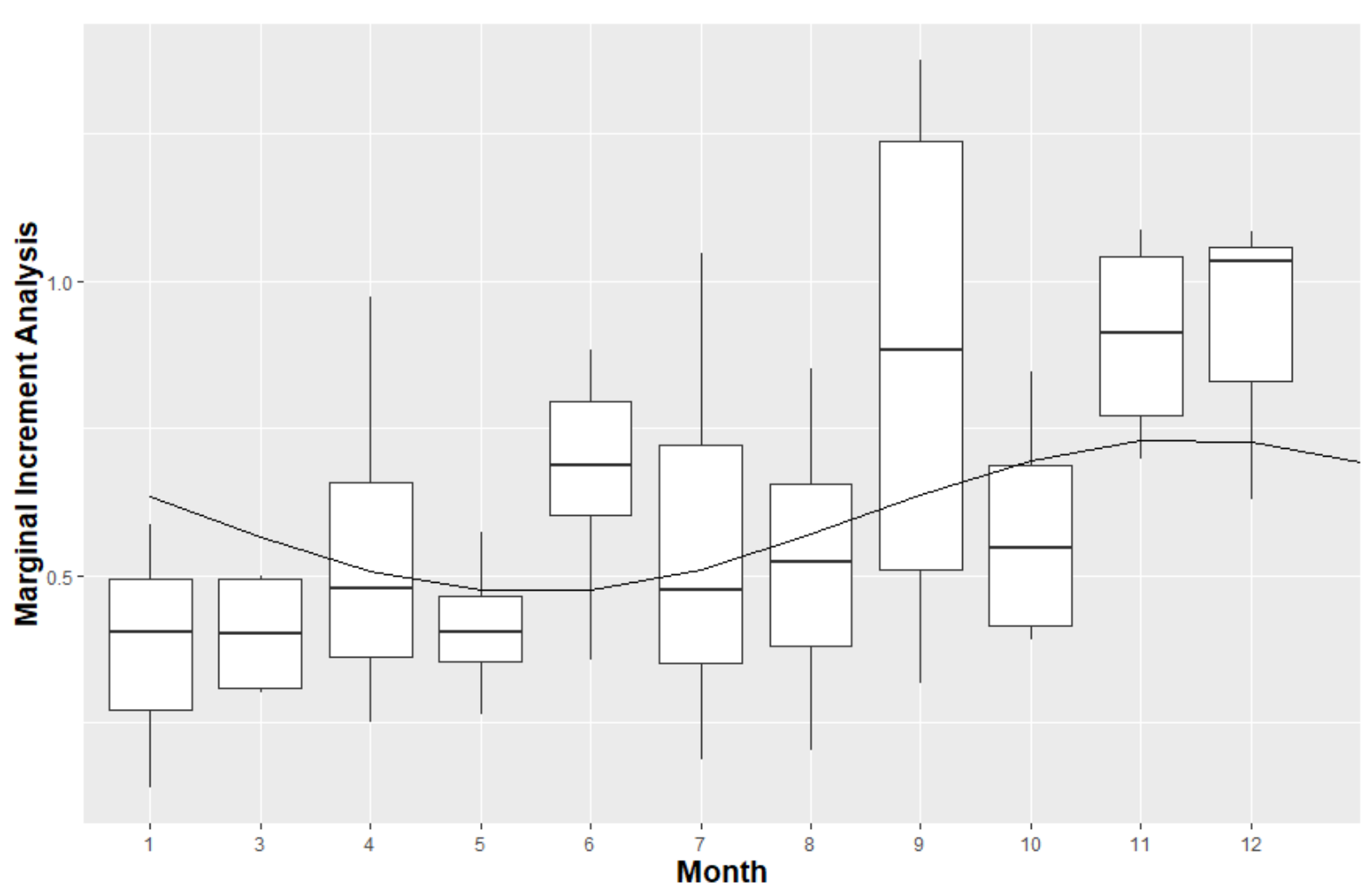


1112 Supplemental Table 1: Information of each modern specimen. During the first months of 1113 collection, it was not possible to record the sex of individuals. During the subsequent months, 1114 sex was identified by Takayuki Yunoki based on Lo Nostro and Guerrero (1996). Collections 1115 were made on the last days of each month, except for the April collections that were made 1116 during the first days of May (03/05/2016).

\begin{tabular}{|c|c|c|c|c|c|}
\hline $\begin{array}{c}\text { Specimen } \\
\text { number }\end{array}$ & $\begin{array}{c}\text { Pre-Anal } \\
\text { length } \\
(\mathbf{m m})\end{array}$ & $\begin{array}{c}\text { Total } \\
\text { lenght } \\
(\mathbf{m m})\end{array}$ & $\begin{array}{c}\text { Weight } \\
\text { (g) }\end{array}$ & $\begin{array}{l}\text { Date of } \\
\text { capture }\end{array}$ & Sex \\
\hline 4 & 105 & 145 & 3 & $31 / 07 / 2015$ & No data \\
\hline 5 & 121 & 143 & 5 & $31 / 07 / 2015$ & No data \\
\hline 1 & 600 & 830 & 811 & $23 / 08 / 2015$ & No data \\
\hline 10 & 385 & 465 & 185 & $31 / 08 / 2015$ & No data \\
\hline 16 & 215 & 312 & 34 & $31 / 08 / 2015$ & No data \\
\hline 15 & 230 & 320 & 36 & $31 / 08 / 2015$ & No data \\
\hline 13 & 252 & 360 & 48 & $31 / 08 / 2015$ & No data \\
\hline 12 & 310 & 425 & 88 & $31 / 08 / 2015$ & No data \\
\hline 14 & 245 & 350 & 50 & $31 / 08 / 2015$ & No data \\
\hline 11 & 345 & 470 & 135 & $31 / 08 / 2015$ & No data \\
\hline 34 & 350 & 485 & 162 & $31 / 08 / 2015$ & No data \\
\hline 28 & 250 & 351 & 53 & $30 / 09 / 2015$ & No data \\
\hline 27 & 269 & 372 & 64 & $30 / 09 / 2015$ & No data \\
\hline 25 & 305 & 449 & 106 & $30 / 09 / 2015$ & No data \\
\hline 24 & 310 & 450 & 107 & $30 / 09 / 2015$ & No data \\
\hline 31 & 229 & 310 & 72 & $21 / 10 / 2015$ & No data \\
\hline 37 & 162 & 235 & 14 & $23 / 10 / 2015$ & No data \\
\hline 36 & 254 & 350 & 58 & $23 / 10 / 2015$ & No data \\
\hline 35 & 325 & 450 & 127 & $23 / 10 / 2015$ & No data \\
\hline 33 & 385 & 530 & 196 & $23 / 10 / 2015$ & No data \\
\hline $00-8$ & 295 & 435 & 94 & $23 / 11 / 2015$ & Female 1 \\
\hline $00-10$ & 269 & 391 & 65 & $23 / 11 / 2015$ & Female 1 \\
\hline $00-12$ & 226 & 328 & 34 & $23 / 11 / 2015$ & Female 1 \\
\hline $00-13$ & 252 & 350 & 33 & $23 / 11 / 2015$ & Male 1 \\
\hline $12-08$ & 316 & 466 & 87 & $23 / 12 / 2015$ & Female 3 \\
\hline $12-09$ & 315 & 441 & 94 & $23 / 12 / 2015$ & Female 1 \\
\hline $12-10$ & 226 & 325 & 33 & $23 / 12 / 2015$ & Female 2 \\
\hline $12-11$ & 228 & 313 & 32 & $23 / 12 / 2015$ & Female 3 \\
\hline $12-12$ & 207 & 299 & 26 & $23 / 12 / 2015$ & Female 1 \\
\hline $0-8$ & 290 & 415 & 71 & $26 / 01 / 2016$ & Female 1 \\
\hline $0-9$ & 296 & 412 & 79 & $26 / 01 / 2016$ & Female 3 \\
\hline $0-10$ & 247 & 355 & 31 & $26 / 01 / 2016$ & Female 1 \\
\hline 03-1 & 362 & 502 & 155 & $29 / 03 / 2016$ & Male 1 \\
\hline
\end{tabular}




\begin{tabular}{|c|c|c|c|c|c|}
\hline $03-2$ & 315 & 446 & 103 & $29 / 03 / 2016$ & Male 1 \\
\hline $03-3$ & 286 & 412 & 85 & $29 / 03 / 2016$ & Female 2 \\
\hline $03-4$ & 267 & 392 & 76 & $29 / 03 / 2016$ & Male 1 \\
\hline $03-5$ & 170 & 242 & 14 & $29 / 03 / 2016$ & Male 1 \\
\hline $05-17$ & 323 & 460 & 118 & $03 / 05 / 2016$ & Male 1 \\
\hline $05-18$ & 320 & 450 & 105 & $03 / 05 / 2016$ & Male 1 \\
\hline 05-19 & 303 & 434 & 112 & $03 / 05 / 2016$ & Male 1 \\
\hline $05-20$ & 301 & 390 & 70 & $03 / 05 / 2016$ & Male 1 \\
\hline $05-21$ & 215 & 300 & 30 & $03 / 05 / 2016$ & Female 1 \\
\hline $05-22$ & 203 & 255 & 19 & $03 / 05 / 2016$ & Male 1 \\
\hline $05-24$ & 380 & 520 & 203 & $03 / 05 / 2016$ & Male 1 \\
\hline $05-25$ & 245 & 342 & 60 & $03 / 05 / 2016$ & Female 1 \\
\hline $05-1$ & 186 & 261 & 26 & $30 / 05 / 2016$ & Female 1 \\
\hline $05-2$ & 279 & 384 & 65 & $30 / 05 / 2016$ & Male 1 \\
\hline $05-3$ & 272 & 395 & 79 & $30 / 05 / 2016$ & Female 1 \\
\hline $05-4$ & 299 & 405 & 72 & $30 / 05 / 2016$ & Male 1 \\
\hline $06-5$ & 385 & 534 & 276 & $30 / 06 / 2016$ & Male 1 \\
\hline $06-6$ & 365 & 501 & 178 & $30 / 06 / 2016$ & Male 1 \\
\hline $06-7$ & 306 & 432 & 165 & $30 / 06 / 2016$ & Female 2 \\
\hline $06-8$ & 323 & 443 & 109 & $30 / 06 / 2016$ & Female 1 \\
\hline $06-9$ & 232 & 321 & 78 & $30 / 06 / 2016$ & Female 1 \\
\hline $06-10$ & 262 & 350 & 82 & $30 / 06 / 2016$ & Female 1 \\
\hline 07-1 & 497 & 680 & 460 & $28 / 07 / 2016$ & Female 1 \\
\hline $07-2$ & 323 & 419 & 126 & $28 / 07 / 2016$ & Female 1 \\
\hline $07-3$ & 334 & 457 & 157 & $28 / 07 / 2016$ & Male 1 \\
\hline $07-4$ & 247 & 358 & 57 & $28 / 07 / 2016$ & Female 1 \\
\hline $07-5$ & 244 & 342 & 50 & $28 / 07 / 2016$ & Female 1 \\
\hline $07-6$ & 240 & 340 & 51 & $28 / 07 / 2016$ & Female 1 \\
\hline $07-7$ & 220 & 305 & 28 & $28 / 07 / 2016$ & Male \\
\hline $07-8$ & 186 & 260 & 20 & $28 / 07 / 2016$ & Female 1 \\
\hline $07-9$ & 229 & 410 & 91 & $28 / 07 / 2016$ & Female 1 \\
\hline $07-10$ & 254 & 347 & 44 & $28 / 07 / 2016$ & Female 1 \\
\hline
\end{tabular}

